\title{
Cryptosporidium Pathogenicity and Virulence
}

\author{
Maha Bouzid, ${ }^{a}$ Paul R. Hunter, ${ }^{a}$ Rachel M. Chalmers, ${ }^{b}$ Kevin M. Tyler ${ }^{a}$ \\ Biomedical Research Centre, Norwich School of Medicine, University of East Anglia, Norwich, England, United Kingdoma; Cryptosporidium Reference Unit, Public Health \\ Wales Microbiology, Singleton Hospital, Swansea, United Kingdom ${ }^{\text {b }}$
}

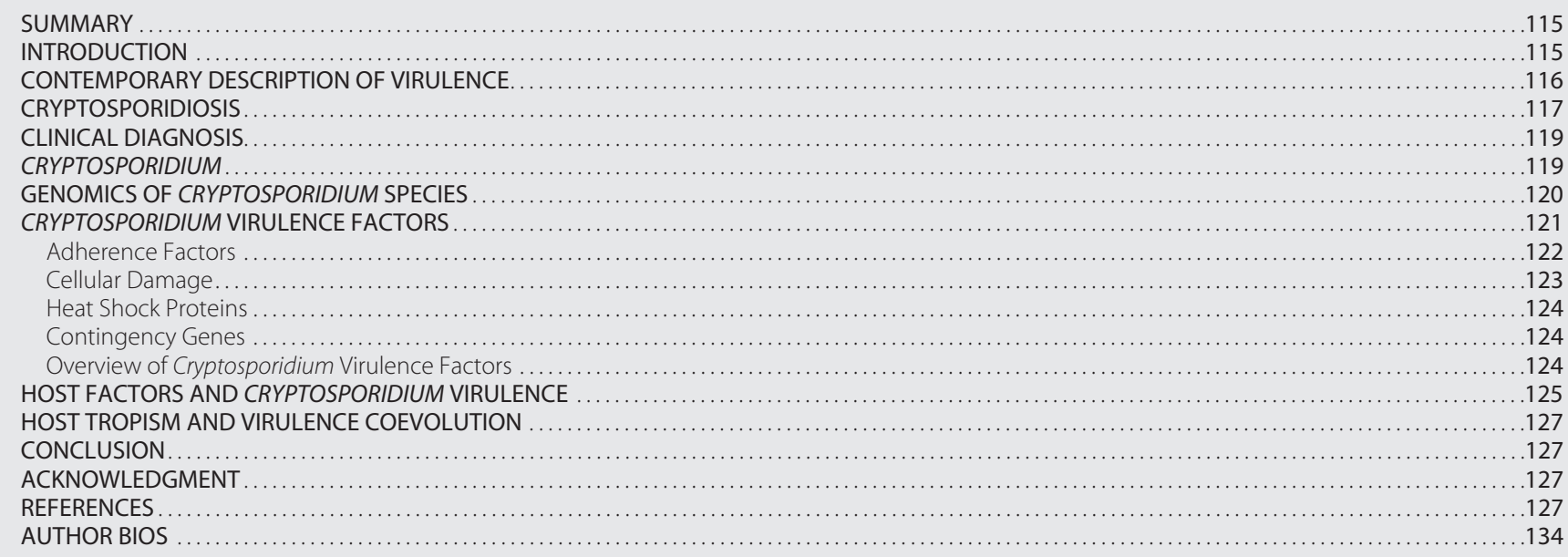

\section{SUMMARY}

Cryptosporidium is a protozoan parasite of medical and veterinary importance that causes gastroenteritis in a variety of vertebrate hosts. Several studies have reported different degrees of pathogenicity and virulence among Cryptosporidium species and isolates of the same species as well as evidence of variation in host susceptibility to infection. The identification and validation of Cryptosporidium virulence factors have been hindered by the renowned difficulties pertaining to the in vitro culture and genetic manipulation of this parasite. Nevertheless, substantial progress has been made in identifying putative virulence factors for Cryptosporidium. This progress has been accelerated since the publication of the Cryptosporidium parvum and C. hominis genomes, with the characterization of over 25 putative virulence factors identified by using a variety of immunological and molecular techniques and which are proposed to be involved in aspects of host-pathogen interactions from adhesion and locomotion to invasion and proliferation. Progress has also been made in the contribution of host factors that are associated with variations in both the severity and risk of infection. Here we provide a review comprised of the current state of knowledge on Cryptosporidium infectivity, pathogenesis, and transmissibility in light of our contemporary understanding of microbial virulence.

\section{INTRODUCTION}

O ur understanding of infectious diseases has been deeply influenced by the fathers of microbiology, Robert Koch and Louis Pasteur, who independently demonstrated the relationship between the microbial world and disease (1). Their work and rationale led directly to the identification and characterization of the etiological agents of the world's major infectious diseases. Subsequent investigators, however, noted that the causal relationship between microbes and disease can be less straightforward than originally envisaged by Koch and Pasteur, with a variety of host and pathogen factors affecting the occurrence and outcome of disease, particularly in cases of opportunistic infections associated with a compromised host immune system. In considering this dichotomy, Isenberg reflected in 1988 that while "doubt about the meaning of pathogenicity and virulence seems inappropriate, if not ridiculous," the traditional vocabulary associated with infectivity and virulence was nevertheless insufficiently well defined to accommodate contemporary observations of clinically important infectious diseases (1). Despite the work of Isenberg and others to clarify and unify a set of appropriate descriptive terminology in this area, some confusion persists, undermining contributions from the major technological advances of our time: genome sequencing, real-time PCR, DNA microarrays, transcriptomics, genetic manipulation, RNA silencing, monoclonal antibodies, fluorescence imaging techniques, and proteomics. This confusion correlates with the fact that the majority of the virulence factors from the microorganisms responsible for the world's most prevalent diseases remain poorly defined and uncharacterized. In this review, we begin by providing a straightforward and generically applicable lexicon for the discussion of pathogenicity and virulence and subsequently focus on the medically important waterborne protozoan parasite Cryptosporidium sp., synthesizing modern studies, especially the elucidation of the Cryptosporidium parvum and C. hominis genomes, which were complemented by

Address correspondence to Paul R. Hunter, Paul.Hunter@uea.ac.uk. Copyright $\odot 2013$, American Society for Microbiology. All Rights Reserved. doi:10.1128/CMR.00076-12 
existing and ongoing research describing the virulence factors which may underpin the molecular mechanisms of Cryptosporidium pathogenesis.

\section{CONTEMPORARY DESCRIPTION OF VIRULENCE}

Virulence is commonly defined simply as the ability of a microorganism to cause disease (2-9). Virulence and pathogenicity are often used interchangeably, but virulence may also be used to indicate the degree of pathogenicity, where pathogenicity is used solely to describe the ability of a pathogen to inflict damage to the host. Virulence is commonly used to describe the likelihood of an infected person becoming ill as well as the severity of symptoms. Thus, virulence could be considered an increased risk of infection and/or an increased severity of illness, and in light of this, Woolhouse and colleagues (10) defined virulence as, "the direct or indirect reduction in host fitness attributable to pathogen infection." Pathogen-centered views of virulence assert that pathogens are distinguished from nonpathogens by their expression of virulence factors. Although this concept appears to apply to some microbes that cause disease in healthy hosts, it has been pointed out that this does not apply to microbes that, like Cryptosporidium, cause serious disease primarily in immunocompromised hosts (11). While earlier definitions of pathogen-centered pathogenicity and virulence are understandable, the modern consensus is that neither microbe nor host characteristics can independently cause disease (12). Virulence, despite being a microbial characteristic, can exist only in a susceptible host and depends on the context and nature of the host-microbe interaction. Thus, a qualified description of virulence with which we concur can be phrased as a pathogen property which can be modulated by host susceptibility and resistance and which causes damage to the host (12). This description takes into account the complexity of host-pathogen interactions and the contribution of both parties to virulence and uses host damage to define virulence (11).

The view that virulence is a single characteristic, however, is difficult to reconcile with the fact that host-pathogen interactions are continuous and subject to changes in host, microbial, and exogenous factors (11). In fact, virulence is usually multifactorial, involving a complex interplay between the parasite and the host. Various host factors, including age, sex, and the status of the immune system, affect the outcome of the hostparasite interaction (13). In addition, the genotypic and phenotypic characteristics of the parasite define intrinsic diversity in isolate pathogenicity and virulence (14). Therefore, an integrated view of microbial pathogenesis and virulence accounting for the contribution of both host and pathogen factors and accommodating a spectrum of host-pathogen interactions provides a more accurate perspective $(10,12)$.

Each of the microbiological attributes that contribute to virulence can, in general, be linked to specific structural elements or biochemical compounds within the organism; these are generally termed virulence factors. Although the terms "virulence determinants" and "virulence factors" are widely used to describe traits contributing to pathogenicity, a subtle distinction exists between the two terms. Virulence factors are "microbial traits that promote host damage" (8), and more precisely, a virulence factor is a gene product necessary but not sufficient to cause disease. In this context, virulence factors can be defined as "contributory virulence factors" (11), which are not singular determinants of virulence but are able to influence the severity and duration of the disease; there- fore, the mutation of such virulence factors should still allow the pathogen to cause disease. This can be illustrated by the significantly reduced (but still present) virulences of a variety of mutant strains (15). Conversely, virulence determinants are "the factors present in a microorganism that are responsible for the relative capacity of a parasite to cause damage in a host" (13), although perhaps a more useful, specific definition of a virulence determinant could be a gene enabling an organism to colonize the host successfully and which may then result in host pathology. An operational definition used for the identification of virulence determinants in experiments is a gene belonging to a pathogen whose inactivation or deletion leads to a loss of virulence of the pathogen and whose genetic reintroduction restores virulence (2). Consistent with this, virulence determinants are most straightforwardly defined as "requisite virulence factors" (11). The identification of virulence factors and virulence determinants for Cryptosporidium spp. is not straightforward and is even more complicated in particular settings such as host immune disorders. For simplicity and clarity in this review, we concur with and have adopted the terminology of Casadevall and Pirofski describing virulence factors as contributory but virulence determinants as requisite (11).

On a practical note, Edberg (16) stated, "For a microbe to generate disease, a number of sequential virulence factors must be active. While clearly the genes that code for virulence must be present in the microbe, disease generation is a phenotypic phenomenon." An implication of this is that the presence of a virulence gene does not necessarily mean that it will be expressed or active, so the possession of a virulence factor gene does not necessarily equate with virulence per se. It is important to take this into account when considering appropriate methodologies for the detection and tracking of virulent strains. For instance, in many cases, genotype testing by PCR cannot definitively determine whether a strain is virulent but merely that it encodes a virulence determinant and thus is potentially virulent. In such cases, however, expression-based assays such as immunofluorescence assays (IFAs), enzyme-linked immunosorbent assays (ELISAs), or, indeed, mass spectrometry may be more appropriate alternatives, better able to discriminate a virulent phenotype (17).

Virulence factors are likely to be involved in adhesion, colonization, invasion, and host immune evasion. When characterized, most factors share one or more of the following properties: (i) they are externally exposed, either on the surface of the parasite or as secreted proteins; (ii) they are hypervariable between isolates; (iii) they are encoded telomerically or subtelomerically; (iv) they are multicopy or belong to gene families; and (v) they are glycosylated and/or lipoylated. Virulence factors have long been considered important microbial traits, and decades of research have been dedicated to the identification of such factors. Such efforts have been rewarded by the discovery of many and diverse microbial genes/molecules that mediate damage and disease in infected hosts. In bacteria, virulence factors are frequently located in pathogenicity islands and can be transferred via plasmids or lysogenic bacteriophages. Classical bacterial virulence factors include toxins, fimbriae, and flagella (18), while in single-celled eukaryotic pathogens, perhaps the best-characterized virulence factors are hypervariable surface proteins such as those that enable antigenic variation (19). Other surface virulence factors of protozoa also have well-established roles in adhesion (20), cell invasion (21), resistance to the host immune response (22), intracellular survival (23), and nutrient uptake (24), while secreted protozoan virulence 
factors can vary considerably in character, from cytotoxic proteases (25), to signaling molecules capable of dysregulating homeostasis (26), to molecules involved in quorum sensing (27). In the postgenomic era, the discovery and validation of protozoan virulence factors in particular have been accelerated by the application of technological advances, including comparative genomics, transcriptomics, microarrays, and reverse genetics including gene replacement and small interfering RNA (siRNA).

When considering how each individual virulence factor contributes to an overall virulence phenotype, it is crucial to identify reliable measures of virulence $(2,8,28)$. The ability of a microbe to cause disease in an animal model, which is central to Koch's postulate, has been the cornerstone of the measurement of virulence, but this relies on the availability of a susceptible experimental animal model (11). Some commonly used measures of virulence are mortality, morbidity, microbial burden, weight loss, condition, and the lifetime reproductive success of infected hosts versus uninfected hosts $(2,8,28)$. Increasingly, additional measurements of virulence, such as different measures of host cell damage (both in vitro and in vivo) and the magnitude and type of inflammatory and immune responses elicited by the pathogen, are being introduced (11). The advent of such parameters provides researchers with useful laboratory-based and epidemiological assessments with which to consider the contribution of virulence factors to strain pathogenicity in cases where access to an animal model is not appropriate or feasible.

\section{CRYPTOSPORIDIOSIS}

Cryptosporidium was first described in the early 20th century; Cryptosporidium muris and C. parvum were the first species described $(29,30)$. The veterinary importance of Cryptosporidium spp. was highlighted by the associations of $C$. meleagridis with morbidity and mortality in turkeys in the 1950s (31) and of $C$. parvum with bovine diarrhea in the early 1970s (32). C. parvum is now regarded as an economically important cause of neonatal diarrhea in calves and lambs (33-39). Another species, Cryptosporidium baileyi, is recognized as an important cause of respiratory disease in poultry and game birds (40-43).

The first cases of human cryptosporidiosis were reported in 1976 in patients with severe watery diarrhea $(44,45)$. Debilitating disease, chronic infections, and high mortality rates identified in AIDS patients during the early 1980s led to the inclusion of cryptosporidiosis as an AIDS-defining illness. Immunocompromised HIV/AIDS patients with T cell counts of $<50$ are now regarded as being at the greatest risk $(43,46-51)$. The public health significance of cryptosporidiosis became apparent when Cryptosporidium was recognized as a common cause of acute diarrhea in immunocompetent individuals $(47,52,53)$. Cryptosporidium spp. are now recognized as major waterborne parasites worldwide (54).

Cryptosporidiosis characteristically results in watery diarrhea that may sometimes be profuse and prolonged $(33,55)$. Diarrhea and abdominal pain are generally the symptoms which cause patients to seek medical attention, leading to a laboratory diagnosis of cryptosporidiosis. Other clinical features include nausea, vomiting, and low-grade fever. Occasionally, nonspecific symptoms such as myalgia, weakness, malaise, headache, and anorexia occur (33). The severity, persistence, and ultimate outcome of the infection are typically dependent on a variety of parasite characteristics and host factors. Host factors include both the immune status and frequency of exposure of the infected individual; however, little is known regarding the pathogenic characteristics of Cryptosporidium spp. (55). The severity of a Cryptosporidium infection can vary from an asymptomatic shedding of oocysts to a severe and life-threatening disease. Immunocompetent individuals experience a transient self-limiting illness (up to 2 to 3 weeks). However, for immunocompromised patients, cryptosporidiosis can be a critical illness with persistent symptoms leading to dehydration and wasting $(43,56,57)$ and was associated with significant mortality rates $(58,59)$. In addition, Cryptosporidium infection can cause atypical manifestations in immunocompromised patients, such as atypical gastrointestinal disease, biliary tract disease, respiratory tract disease, and pancreatitis (60). A review summarizing clinical features in immunocompetent and immunocompromised patients was recently published (61).

Although several Cryptosporidium species have been identified in humans, C. hominis and C. parvum account for more than $90 \%$ of human cases of cryptosporidiosis (62-64). Other species that have less commonly been associated with human disease globally include C. meleagridis, C. cuniculus, C. felis, and C. canis; however, this is setting dependent. Although the clinical presentations of $C$. parvum and $C$. hominis infections are very similar, several variants have been reported. Cama and colleagues reported differences in clinical manifestations among Cryptosporidium species and subtypes in HIV-infected persons and in children $(65,66)$, with $C$. hominis being associated mainly with diarrhea, nausea, vomiting, and malaise and C. parvum, C. meleagridis, C. canis, and C. felis being associated with diarrhea only. In addition, it was shown that C. hominis infection was associated with nonintestinal sequelae (joint pain, eye pain, recurrent headache, and fatigue), which were not reported for people infected with C. parvum (67).

Direct and several indirect routes of transmission of Cryptosporidium have been identified. Direct transmission occurs by the fecal-oral route from infected hosts, including animal-to-animal, animal-to-human (zoonotic), human-to-animal, and human-tohuman (anthroponotic) transmissions $(66,68-70)$. Person-toperson spread is well described as secondary cases, especially in families and in outbreak settings (71), including institutions such as day care centers and hospitals (72). Epidemiological and microbiological evidence for the zoonotic transmission of cryptosporidiosis comes from outbreaks involving veterinary students and researchers who had contact with infected young calves and involving children visiting farms where the same strain type was identified in animals and people. Indirect transmission involves contact with Cryptosporidium fecally contaminated material, including water, food, and fomites such as clothes and footwear. Indirect transmission also occurs through environmental contamination, usually involving the release of feces, sewage, wastewater, or slurry, often as overflow following heavy-rain events (73-75). Another mode of transmission, via the inhalation of oocysts, was reported for immunocompromised patients and for children (76-78) and was supported by data from experimental intranasal infections of piglets (79). The symptoms associated with this route are respiratory (laryngotracheitis) and could be accompanied by mild diarrhea.

Most of the data on transmission pathways for Cryptosporidium come from reports of outbreaks, the majority of which are waterborne $(54,80-83)$. However, outbreaks represent only a small proportion of recorded cryptosporidiosis cases. The transmission routes for endemic diseases may or may not be the same as 
TABLE 1 Cryptosporidium risk factors determined by case-control studies in developed nations, reported since the early $1990 \mathrm{~s}^{a}$

\begin{tabular}{|c|c|c|c|c|c|}
\hline Reference & Location & No. of cases & No. of controls & Significant risk factor & Odds ratio $(95 \% \mathrm{CI})^{b}$ \\
\hline 85 & Melbourne, Australia & 201 & 795 & $\begin{array}{l}\text { Eating uncooked carrots } \\
\text { Swimming in public pool } \\
\text { Children aged }<6 \mathrm{yr} \text { at home with diarrhea } \\
\text { Persons aged }>5 \mathrm{yr} \text { at home with diarrhea } \\
\text { Animal contact in home } \\
\text { Calf contact away from home } \\
\text { Drinking unboiled water from river, lake, or dam }\end{array}$ & $\begin{array}{l}0.6(0.4-0.9) \\
2.7(1.9-3.8) \\
7.4(4.0-13.8) \\
1.8(1.1-2.9) \\
0.6(0.4-0.8) \\
2.9(1.5-5.7) \\
1.5(0.8-2.7)\end{array}$ \\
\hline 67 & Wales and England & 427 & 427 & $\begin{array}{l}\text { Travel outside UK } \\
\text { Case contact } \\
\text { Touching cattle } \\
\text { Toileting child aged }<5 \mathrm{yr} \\
\text { No. of glasses unboiled water } \\
\text { Eating ice cream } \\
\text { Eating raw vegetables } \\
\text { Eating tomatoes }\end{array}$ & $\begin{array}{l}5.7(2.9-11.2) \\
4.6(2.4-8.7) \\
3.9(1.4-10.0) \\
1.9(1.1-3.2) \\
1.1(1.0-1.3) \\
0.5(0.3-0.7) \\
0.5(0.3-0.8) \\
0.6(0.4-1.0)\end{array}$ \\
\hline
\end{tabular}

\footnotetext{
${ }^{a}$ Adapted from reference 69 with permission from Elsevier and updated with data from references 87,88 , and 89 .
}

${ }^{b} \mathrm{CI}$, confidence interval.

those in outbreak settings. This has been evaluated in case-control studies, the majority of which were reviewed by Yoder and Beach (84) and Hunter and Thompson (69). The key risk factors are the ingestion of contaminated drinking or recreational water, contact with infected persons or animals, travel to areas where the disease is endemic, and contact with children $<6$ years old (especially but not exclusively with diarrhea), as shown in Table 1 . These investigations also showed a consistent negative association with the eating of raw vegetables. It has been suggested that repeated exposures to small numbers of Cryptosporidium oocysts on raw vegetables provide protective immunity. This hypothesis was supported by Frost and colleagues (90), who conducted a diary-based study for which participants were asked to record the occurrence of diarrheal or gastrointestinal symptoms. The authors reported that higher levels of anti-Cryptosporidium antibodies were associated with reduced rates of diarrhea. Those authors suggested that the lower levels of illness in people with increased levels of antibodies may be due to enhanced immunity from repeated exposures to oocysts in drinking water. It is important to keep in mind that these cryptosporidiosis risk factors are relevant in industrialized nations and that the settings and challenges are very different in developing countries. In immunocompromised subjects, mainly those with HIV infection, several studies investigated the specific risk factors for this high-risk group and found that the drinking of tap water from an untreated supply, exposure to pets and animals, unsafe sexual activity, and the use of public toilets are associated with Cryptosporidium infection (91-93).

The epidemiology of Cryptosporidium has been investigated mainly at the genus level $(85,86,94-98)$; however, as $C$. hominis and C. parvum have different host ranges and transmission cycles, it is likely that those epidemiological studies that looked at risk factors for both species combined will have emphasized risk fac- 
tors common to both species and downplayed risk factors unique to one species or the other (69). To address this, a case-control study that discriminated $C$. hominis from $C$. parvum was performed with immunocompetent subjects, enabling the identification of species-specific risk factors (67). The major risk factor for C. parvum was the touching or handling of farm animals, while for C. hominis, the main risk factors were travel outside the United Kingdom and diaper changing, even of asymptomatic infants. Based on this observation, it was suggested that the main reservoir for C. parvum infection is indeed zoonotic, while for C. hominis, the most important reservoir may be asymptomatic carriage in young children. Subsequently, several epidemiological investigations using identification of isolates to the species level (99-101) and even subtyping (102-107) have been reported. One of the key findings was the description of a subtype of C. parvum (subtype IIc) that appears to be anthropogenic and not zoonotic $(66,108$, 109). The identification of isolates to the species level has improved our understanding of the epidemiology of and risk factors for cryptosporidiosis and has been valuable in outbreak investigations (103). In recent years, the epidemiology of Cryptosporidium has been extensively reviewed $(55,60,62,69,70,84,110-114)$.

\section{CLINICAL DIAGNOSIS}

The symptoms of cryptosporidiosis are not pathognomonic; laboratory verification is required to confirm the diagnosis. This is usually done by the detection (presence or absence) of oocysts in stool samples by a microscopic examination of smears stained with tinctorial stain (usually acid fast, such as modified ZiehlNeelsen stain), fluorescent stain (such as auramine O), or immunofluorescent stain (115). Alternatively, oocyst antigen capture methods such as enzyme immune assays (EIAs) or immunochromatographic lateral flow (ICLF) assays may be used (115), and positive reactions must be confirmed by using a suitable confirmatory test (116). The detection of Cryptosporidium DNA by PCR is also used in some diagnostic laboratories (117), usually as part of a multiplex gastrointestinal pathogen panel or parasite panel, for example, with Giardia duodenalis, Entamoeba histolytica, and Dientamoeba fragilis (118). Commercial assays are becoming available, for which the target loci are not always revealed by the manufacturer, but for in-house Cryptosporidium detection assays, these include unspecified regions (119) and the small-subunit (SSU) rRNA gene (120).

The diagnostic sensitivities of routine tests have been compared, demonstrating the superior performance of immunofluorescence microscopy and PCR over comparable performances of EIAs and fluorescent stains, which in turn were better than acidfast staining and ICLF assays (121). The specificity of microscopy depends largely on the skill of the microscopist to differentiate oocysts from other bodies in smears stained with nonspecific tinctorial and fluorescent reagents; immunofluorescent stains are more specific (115). Test selection will also depend on additional multiple attributes and the resources available to meet them, including technical expertise, turnaround time, performance in batch mode, hands-on time, consumables cost per test or batch, and specialist equipment (121).

For some patients, especially those who are severely immunocompromised, alternative samples may be more appropriate, and endogenous life cycle stages may be sought by the histological staining of gastrointestinal or other biopsy samples. PCR-based methods for the detection of Cryptosporidium DNA may also be applied following tissue digestion and to sample types such as antral wash, bile, and bronchoalveolar lavage fluid specimens, as indicated by the patient's symptoms (122).

PCR detection from stool samples depends on effective DNA extraction, which is hampered by the robust oocysts, which require additional disruption steps, such as chemical treatment, bead beating, freeze-thaw cycles, or boiling, to access the sporozoite DNA. PCRs, where applied in routine diagnostic settings, are part of multiplex gastrointestinal parasite panels and can identify the Cryptosporidium genus but not the species. Species identification by PCR-restriction fragment length polymorphism (RFLP), PCR sequencing, or real-time PCR assays is usually performed as a reference test in specialist laboratories and is applied more comprehensively in some countries than in others (114).

There is no standardized subtyping method, although sequence analysis of the gp60 gene has been applied to further characterize C. parvum and C. hominis; single-locus typing will underestimate diversity, as it ignores the potential for genetic recombination within Cryptosporidium sp. populations during reproduction (123), and standardized, multilocus subtyping schemes need to be validated to support epidemiological investigations (124).

\section{CRYPTOSPORIDIUM}

Cryptosporidium is an apicomplexan parasite of public health and veterinary importance. This phylum contains other medically important parasites such as Plasmodium and Toxoplasma. Most apicomplexan parasites are characterized by the presence of an organelle called an apicoplast. In addition, the invasive forms have an apical complex, comprising polar rings, rhoptries, micronemes, and conoid and subpellicular microtubules, which is involved in host-parasite interactions. Interestingly, Cryptosporidium spp. seem to have lost functional apicoplasts and mitochondria, as shown by genome sequence analyses.

The Cryptosporidium life cycle can be divided into six major developmental phases (33): excystation (the release of infective sporozoites), merogony (asexual multiplication within host cells), gametogony (the formation of micro- and macrogametes), fertilization (the union of micro- and macrogametes), oocyst wall formation (to produce the environmentally resistant stage responsible for the transmission of the infection from one host to another), and sporogony (the formation of infective sporozoites). Cryptosporidium species have a monoxenous life cycle completed within the gastrointestinal tract of a single host. During the whole cycle, the different forms are confined to the apical surfaces of the host cells. The infective forms attach to the apical surfaces by a poorly understood process and become internalized within an intracellular but extracytoplasmic compartment separated from the cytoplasm by an electron-dense layer that appears to be predominantly of host origin (125). The parasite is located within a closed compartment of the host cell plasmalemma, described as the parasitophorous vacuole (126), where it is protected from the hostile gut environment and is supplied with energy and nutrients by the host cell through a feeder organelle, which is unique among apicomplexan parasites (79). It has also been reported that C. parvum may have extracellular gregarine-like life stages (127), although no subsequent studies have so far confirmed this.

The established life cycle begins with the ingestion of the sporulated oocysts by the susceptible host; the oocysts undergo excystation and release four infective sporozoites (Fig. 1). The excysta- 


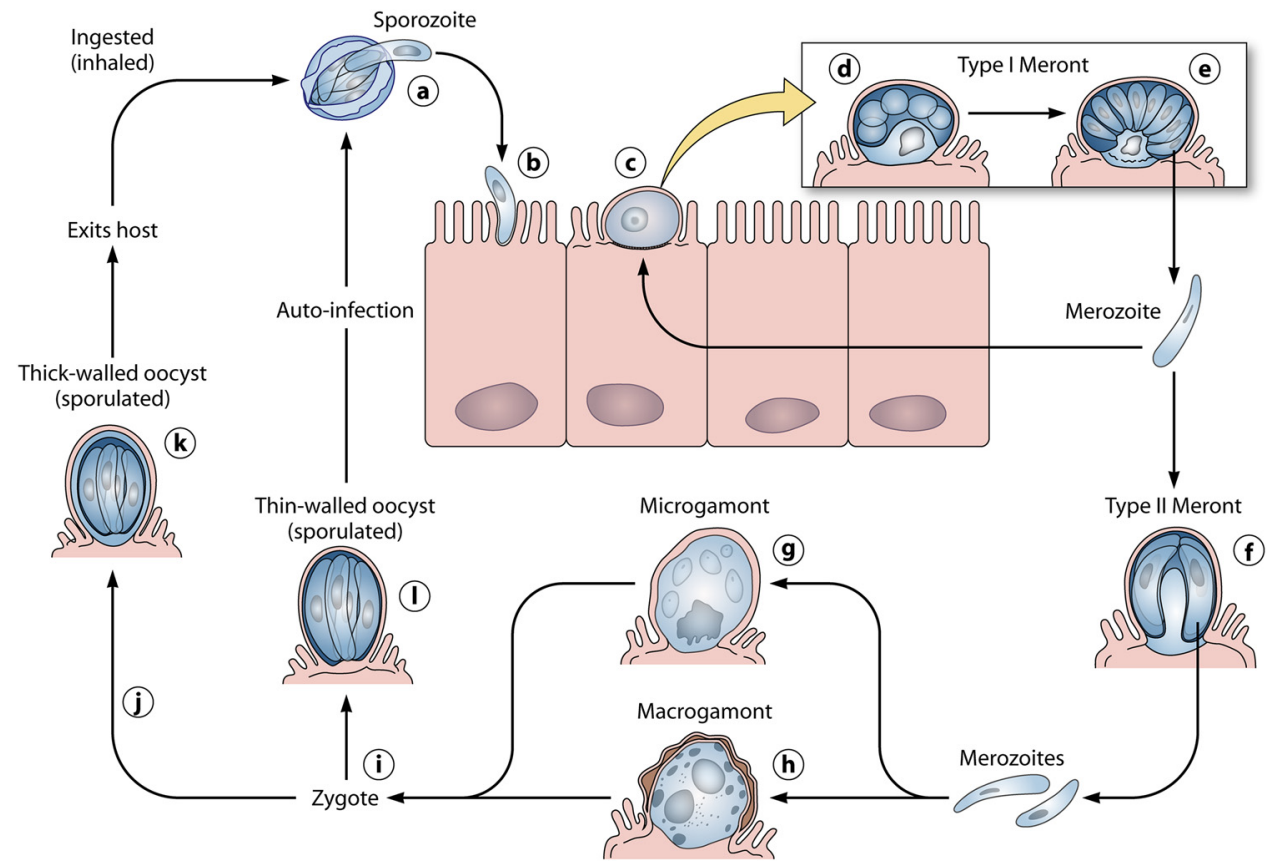

FIG 1 Schematic representation of the Cryptosporidium parvum life cycle. After excysting from oocysts in the lumen of the intestine (a), sporozoites (b) penetrate host cells and develop into trophozoites (c) within parasitophorous vacuoles confined to the microvillous region of the mucosal epithelium. Trophozoites undergo asexual division (merogony) ( $\mathrm{d}$ and e) to form merozoites. After being released from type I meronts, the invasive merozoites enter adjacent host cells to form additional type I meronts or to form type II meronts (f). Type II meronts do not recycle but enter host cells to form the sexual stages, microgamonts (g) and macrogamonts (h). Most of the zygotes (i) formed after the fertilization of the microgamont by the microgametes (released from the microgamont) develop into environmentally resistant, thick-walled oocysts $(\mathrm{j})$ that undergo sporogony to form sporulated oocysts (k) containing four sporozoites. Sporulated oocysts released in feces are the environmentally resistant life cycle forms that transmit the infection from one host to another. A smaller percentage of zygotes (approximately 20\%) do not form a thick, two-layered oocyst wall; they have only a unit membrane surrounding the four sporozoites. These thin-walled oocysts (l) represent autoinfective life cycle forms that can maintain the parasite in the host without repeated oral exposure to the thick-walled oocysts present in the environment. (Modified from reference 33 with permission.)

tion of the oocysts has been reported to be triggered upon ingestion by various factors, including reducing conditions, carbon dioxide, temperature, pancreatic enzymes, and bile salts (40, $43,128-130)$. Excystation allows the emergence of the four infectious sporozoites through a suture in the oocyst wall (129). The released sporozoites glide over the intestinal cell, releasing material from the apical complex (13). Gliding motility allows the sporozoites to migrate across the surface of host cells and to actively invade them (131). This form of motility is conserved among different apicomplexan parasites. C. parvum sporozoites undergo circular and helical gliding movements, which are actinmyosin-tubulin dependent $(131,132)$. During gliding motility, sporozoites deposit trails of proteins, which are involved in the attachment to and invasion of host cells (133). Cryptosporidium sporozoites possess an apical complex composed of micronemes, a single rhoptry, and dense granules (134). These secretory organelles are also present in other apicomplexan parasites, such as Toxoplasma, Plasmodium, and Eimeria, and are involved in host cell attachment and invasion $(13,135)$. The pellicle mediates movement and attachment to the host cell membrane via molecules exposed on the surface that drive the movement of the sporozoite, while the rhoptries and micronemes enable the sporozoite to adhere to and invade the cell, inducing the cell membrane to enclose the parasite in the parasitophorous vacuole (135-138). Each sporozoite develops into a spherical trophozoite, which undergoes merogony and forms a type I meront containing eight merozoites (43). These merozoites are released and attach again to the surface of an epithelial cell, where they undergo merogony once more and form either a further type I meront or a type II meront. A type II meront contains four merozoites. These merozoites, when released, attach again to the epithelial cell, but instead of developing into further meronts, they initiate gametogony. Individual merozoites produce either microgamonts or macrogamonts $(139,140)$. Each microgamont undertakes nuclear division and differentiates to form up to 16 microgametes, which, when released from the parasitophorous vacuole, locate and fertilize a unicellular macrogametocyte that has developed from a macrogamont. The product of fertilization, the zygote, undergoes two asexual cycles of sporogony to produce an oocyst with either a thick wall or a thin wall, containing four sporozoites (141). The thick-walled oocysts are released into the lumen of the intestine, are excreted from the host in the feces, and are immediately infective, allowing the spread of infection to other susceptible hosts (140). In addition, unlike other parasites belonging to the same subclass (Coccidia), Cryptosporidium is able to autoinfect the same host. Autoinfection occurs through the thin-walled oocysts, which excyst once they are separated from the epithelium, and the cycle starts again $(141,142)$. Autoinfection and the recycling of type I meronts provide an explanation for persistent chronic infection (143-145).

\section{GENOMICS OF CRYPTOSPORIDIUM SPECIES}

Several studies tried to reveal the characteristics of the Cryptosporidium genome prior to the sequencing era. Karyotypic analyses 
suggested that Cryptosporidium contains eight chromosomes, ranging in size from 0.945 to $2.2 \mathrm{Mb}$, giving a total haploid genome size of approximately $10 \mathrm{Mb}(146,147)$. In addition, $C$. parvum was shown to have two small extrachromosomal cytoplasmic virus-like double-stranded RNAs (1,786 and 1,374 nucleotides, respectively) (148). The RNAs have a single open reading frame each, which encode a putative RNA-dependent RNA polymerase and a protein with limited homology to mammalian protein kinases, respectively (149). Le Blancq and colleagues (150) investigated the C. parvum rRNA gene organization and reported that the small and large rRNA subunits are 1.7 and $3.6 \mathrm{~kb}$, respectively, plus a 151-bp putative 5.8S rRNA. It was also demonstrated that Cryptosporidium does retain some mitochondrial biosynthesis genes (151) but that, unlike other apicomplexans, it lacks an apicoplast (152).

As a pathogen of public health relevance, Cryptosporidium was included in early genome-sequencing projects. Two reference strains served as genome representatives: C. parvum Iowa and $C$. hominis TU502. The genome sequences showed similar genome sizes of 9.11 and $9.16 \mathrm{Mb}$, respectively, with 3 to $5 \%$ sequence divergence $(153,154)$. In addition, the genome sequencing and assembly of C. muris strain RN66, a less relevant Cryptosporidium species from a public health perspective, are essentially complete (155). Genome analysis revealed extremely streamlined metabolic pathways and a lack of many cellular structures and metabolic pathways found in other apicomplexans (133). Energy metabolism is largely from glycolysis, and both aerobic and anaerobic metabolisms are available, thus conferring environmental flexibility (125). Limited biosynthetic capabilities and minimal metabolism have been reported, suggesting a large dependence on nutrient acquisition from the host (156). An extensive array of transporters was discovered, which enable the import of essential nutrients from the host $(154,157)$. Genome sequences showed that Cryptosporidium species have genes associated with apical complex organelles but suggested that they lack an apicoplast and possess only a degenerate mitochondrion which has lost its genome $(153,154)$. The existence of a relict mitochondrion was subsequently confirmed by ultrastructural studies (158). A comprehensive genome database, CryptoDB (http://CryptoDB.org/), serves as a public interface for Cryptosporidium genome sequences (159). This website offers access to sophisticated tools which enable the identification of genes based on text, sequence similarity, and motif queries (160).

The sequencing of Cryptosporidium genomes has revealed a vast amount of information, contributing to a better knowledge of microbial biology, pathogenicity, evolution, and virulence. The quest for the molecular basis of virulence has exploited these genomic data to search for genes that may ultimately unravel the regulation of virulence, host range, and transmissibility at the genetic level (11). Several comparative genomics studies have been performed since the completion of genome sequences from apicomplexan parasites of medical and veterinary importance. Templeton and colleagues (161) showed that Cryptosporidium spp. and Plasmodium spp. share over 150 ancestral "apicomplexan" proteins, involved mainly in interactions with eukaryotic host cells and the biogenesis of the apical complex. Gordon and Sibley (162) used genome sequences of Toxoplasma gondii, Plasmodium spp., Cryptosporidium spp., and Theileria spp. to show the conservation of actin-like proteins among these parasites, which rely on actin-based motility for cell invasion, while comparative genomics of Plasmodium spp., Cryptosporidium spp., and Toxoplasma gondii revealed that calcium-regulated proteins (plant-like pathways for calcium release channels and calcium-dependent kinases) were also conserved (163). In addition to conserved genes, comparative genomics can identify unique, novel, and uncharacterized virulence genes. Kuo et al. (164) compared the genome sequences of three apicomplexan parasites (Plasmodium, Theileria, and Cryptosporidium) and showed that as many as $45 \%$ of the Cryptosporidium genes could be considered genus specific. Although the predicted gene counts were not identical, the papers reporting the genomes of $C$. parvum (3,952 genes) and C. hominis (3,994 genes) found no evidence for unique genes between the species, noting that what variation appeared to be present reflected primarily gaps in one genome or the other and speculating that the phenotypic differences likely arose from polymorphisms in coding regions and differences in gene regulation. The comparative genomics study by Kuo et al. (164), however, identified 334 putative C. hominis-specific genes and 178 putative C. parvumspecific genes by interrogations of the Cryptosporidium database into which the gene sequences had been placed. A similar in silico analysis that compared the genome sequences of $C$. hominis and $C$. parvum, aiming to uncover genetic loci responsible for host preference, showed 93 and 211 putative genes specific for $C$. hominis and C. parvum, respectively (63). However, when tested experimentally, the majority of the genes were found to be present in both species albeit with slight interspecies and intersubtype sequence variability. Nevertheless, PCR results showed experimental evidence for one $C$. hominis-specific and C. parvum-specific genes (165). A subsequent study by Widmer and colleagues which also aimed to investigate the genetic basis of Cryptosporidium host specificity used genome-wide comparisons of C. parvum zoonotic, C. parvum anthroponotic (IIc subtype), and C. hominis isolates (166). Those authors reported that for some genetic loci, there was actually more sequence similarity between $C$. parvum anthroponotic and $C$. hominis strains than there was between $C$. parvum anthroponotic and C. parvum zoonotic strains. A proteomic analysis of C. parvum proteins expressed during excystation showed an overexpression of three apicomplexan-specific and five Cryptosporidium-specific proteins (167). A recent C. parvum kinome analysis showed that several protein kinases of Cryptosporidium are distinct from those of other apicomplexans $(P$. falciparum and T. gondii) (168).

\section{CRYPTOSPORIDIUM VIRULENCE FACTORS}

Several studies have tried to determine the factors responsible for the initiation, establishment, and perpetuation of Cryptosporidium infection. Cryptosporidium does not normally cause a systemic infection or penetrate deep tissue; rather, the parasite establishes itself in a membrane-bound compartment on the apical surface of the intestinal epithelium (13). Nevertheless, it causes significant abnormalities in the absorptive and secretory functions of the gut. This damage could be the result of direct injury to the host epithelial cells or could be indirect through the effect of inflammatory cells and cytokines recruited to the site of infection (13).

Virulence factors are considered to be the processes and substances by which the parasite initiates and maintains disease in the host; these factors can affect the host at any time during the life cycle from the time when the parasite enters the body until it is killed or completes the cycle and exits the host (14). To date, 
TABLE 2 Putative Cryptosporidium virulence factors identified by immunological and molecular methods ${ }^{a}$

\begin{tabular}{|c|c|c|}
\hline Virulence factor & Putative function(s) & Reference(s) \\
\hline Serine protease & Excystation & 229 \\
\hline Aminopeptidase & Excystation & 169 \\
\hline CSL & Adhesion & 170 \\
\hline gp900 & Adhesion & 137 \\
\hline gp60/40/15 & Adhesion & $171-173$ \\
\hline P23 & Adhesion, locomotion & 174,175 \\
\hline P30 & Adhesion & 176 \\
\hline TRAP-C1 & Adhesion, locomotion & 177 \\
\hline Cp47 & Adhesion & 178 \\
\hline CPS-500 & Adhesion, locomotion & 179,180 \\
\hline $\mathrm{Cp} 2$ & Invasion, membrane integrity & 277 \\
\hline Cpa135 & Invasion & 181 \\
\hline Secretory phospholipase & Invasion, intracellular establishment & 182 \\
\hline Hemolysin $\mathrm{H} 4$ & Membrane lysis & 183 \\
\hline CpABC & Transport, nutrient transport & 184 \\
\hline CpATPase2 & $\begin{array}{l}\text { Biomembrane heavy metal } \\
\text { transporter }\end{array}$ & 185 \\
\hline CpATPase3 & $\begin{array}{l}\text { Biomembrane ion or phospholipid } \\
\text { transporter }\end{array}$ & 186 \\
\hline HSP70 & Stress protection & 187 \\
\hline HSP90 & Stress protection & 231 \\
\hline CpPKS1 & Unknown function & 188 \\
\hline Cysteine protease & Immune/cytokine modulation & 189 \\
\hline Acetyl cosynthetase & Fatty acid metabolism & 190 \\
\hline CpSUB & Invasion & 191 \\
\hline CpMIC1 & Adhesion, locomotion & 192 \\
\hline CpMuc & Invasion & 193 \\
\hline
\end{tabular}

${ }^{a}$ Data were compiled from data obtained from references 13, 14, 135, 191, 192 and 193.

Cryptosporidium-specific virulence factors have not been characterized to the point of unequivocally establishing their roles in causing damage to the host or proving that their deletion or inactivation results in a decrease of disease severity (13). This is mainly because, unlike other apicomplexan parasites such as Toxoplasma and Plasmodium, it remains difficult to employ in vitro cultivation and reverse genetics techniques with this parasite, meaning that genes cannot be readily knocked out or knocked down in experiments designed to examine virulence by a straightforward loss or gain of pathogenicity (133).

Putative virulence factors for Cryptosporidium have been identified as genes involved in the initial interaction processes of Cryptosporidium oocysts and sporozoites with host epithelial cells, including excystation, gliding motility, attachment, invasion, parasitophorous vacuole formation, intracellular maintenance, and host cell damage $(14,133)$.

\section{Adherence Factors}

A critical initial step in establishing infection is parasite attachment to host cells. Two classes of proteins, namely, mucin-like glycoproteins and thrombospondin-related adhesive proteins, have been characterized and shown to mediate adhesion (133). The characteristics of these proteins are summarized in Table 2.

CSL (circumsporozoite-like glycoprotein), with a molecular mass of $\sim 1,300 \mathrm{kDa}$, was described by Riggs and colleagues (170) and is associated with the apical complex of sporozoites and merozoites $(194,195)$. CSL is released as a soluble glycoprotein and contains a ligand that binds specifically to a receptor on the surface of human and bovine intestinal epithelial cells (194). The zoite ligand was shown to be involved in attachment and invasion (196). Monoclonal antibodies to CSL elicited changes in sporozoites and merozoites, similarly to the malarial circumsporozoite precipitate (CSP) reaction, and caused the complete neutralization of sporozoite infectivity (170).

Glycoprotein 900 (gp900) is a large glycoprotein identified by the immunoprecipitation of sporozoite extracts with hyperimmune bovine colostrum (137). This large mucin-like glycoprotein is located in micronemes and at the surface of invasive merozoites and sporozoites. gp900 is deposited in trails during gliding motility and is known to mediate invasion $(197,198)$. The deduced amino acid sequence of gp900 has a signal peptide and a transmembrane domain (197). Specific antibodies to gp900 can competitively inhibit infection in vitro $(197,199)$. gp60 N- and C-terminal peptides include a hypothetical signal sequence and a glycosylphosphatidylinositol (GPI) anchor attachment site, which are highly conserved among all Cryptosporidium isolates, suggesting that both features are important (171). The rest of the gene has a high degree of polymorphism, which is far greater than any other Cryptosporidium protein-encoding locus $(109,171,200)$. A typing technique based on the sequence analysis of this polymorphic sporozoite surface glycoprotein has been extensively used and allowed the classification of Cryptosporidium isolates into gp60 subtypes $(108,171,201-210)$. Interestingly, some gp60 subtypes were associated with strain virulence (65). Cama and colleagues (65) reported differences in clinical manifestations between Cryptosporidium species and subtypes in HIV-infected persons and in children $(65,66)$. Similarly, a study in China showed that two subtypes were associated with extended outbreaks in hospitalized children (211).

A sporozoite and merozoite cell surface protein gp15/40/60 complex has been described (Cpgp40/15 in C. parvum and Chgp40/15 in C. hominis): Strong and colleagues (171) reported that gp15/40/60 mRNA is translated into a $\sim 60-\mathrm{kDa}$ glycoprotein precursor during the intracellular stages of the C. parvum life cycle. Independently, Cevallos and colleagues (172) cloned and sequenced the same gene from C. parvum genomic DNA and called it Cpgp40/15. Shortly after synthesis, the $60-\mathrm{kDa}$ precursor is proteolytically processed to generate $15-$ and $45-\mathrm{kDa}$ glycoproteins. gp40 is localized at the surface and the apical region of the parasite and is shed from the surface, while gp15 is on the surface of sporozoites and is shed in trails during gliding movement $(135,172)$. Proteins present in the trails of gliding zoites have been shown to play a role in parasite attachment, invasion, and motility (133, $172,201,212-215)$. In C. parvum, gp15 is attached to the membrane via a GPI anchor (216). Both gp40 and gp15 display O-linked $\alpha$-N-acetylgalactosamine ( $\alpha$-GalNAc), which is thought to be involved in invasion and attachment, since lectins that recognize these determinants block sporozoite attachment $(173,217$, 218). A monoclonal antibody against gp 15 neutralized infectivity in vitro and passively protected against the disease in vivo. It was suggested that a protein complex of gp $900 / \mathrm{gp} 40 / \mathrm{p} 30$ is formed to mediate adhesion via lectin activity $(176,219)$.

P23 is a 23-kDa sporozoite surface protein that is antigenically conserved across geographically diverse isolates (174) and is deposited in trails during the initial stages of infection (175). P23 elicits antibody responses in animals and humans exposed to $C$. parvum (220-223). P23 has neutralization-sensitive epitopes, and monoclonal antibodies were found to significantly reduce infection in mice and protect calves against cryptosporidiosis (135). 


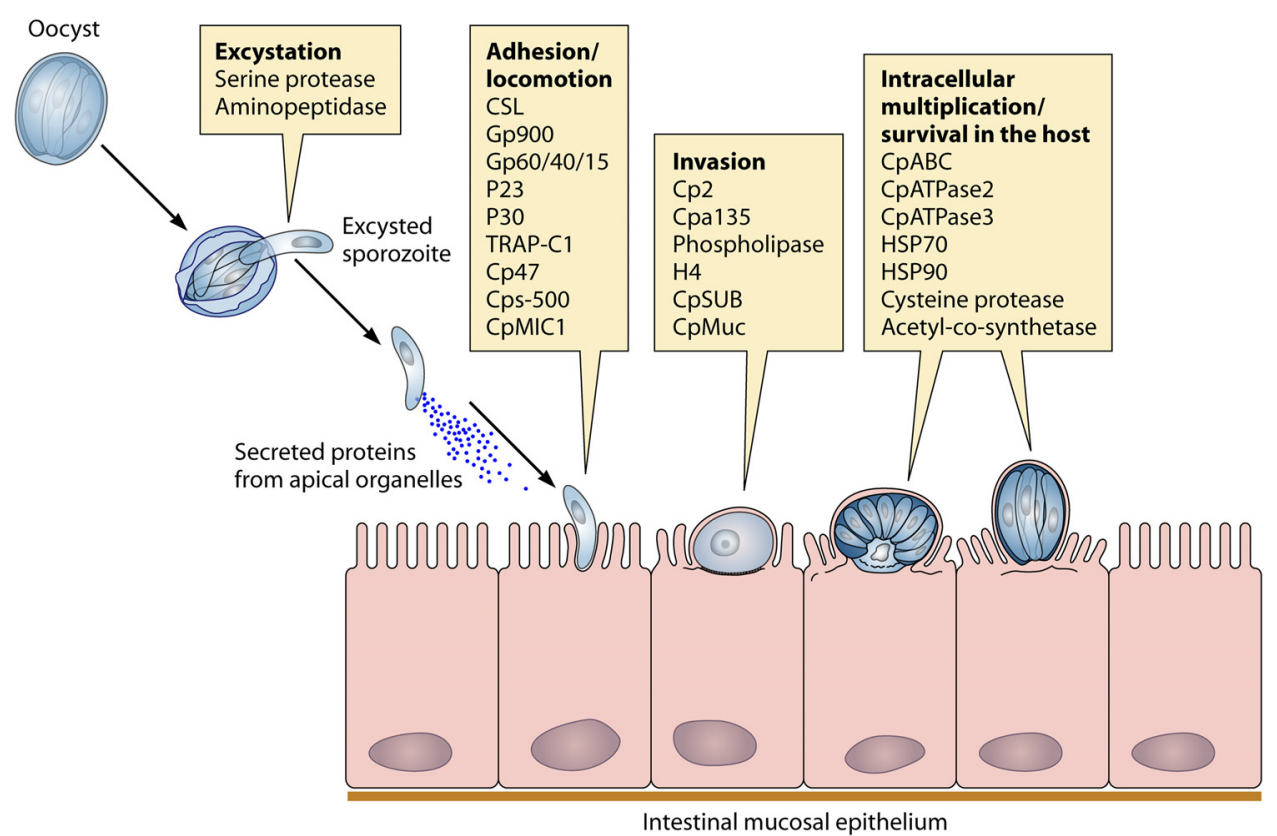

FIG 2 Cryptosporidium virulence factors described to date and their contribution to the parasite life cycle.

Of the micronemal proteins (MICs), TRAP-C1 (thrombospondin-related adhesive protein Cryptosporidium 1) is a 76-kDa protein localized on the apical pole of sporozoites (177). It showed sequence and structural homology to members of the thrombospondin family of adhesive proteins in other apicomplexan parasites (Plasmodium spp., Toxoplasma gondii, Eimeria tenella, and Neospora spp.) (135). TRAP and structurally related proteins are involved in parasite gliding motility and cell penetration (135). Putignani and colleagues (192) characterized "CpTSP8," from a family of 12 C. parvum thrombospondin-related proteins (CpTSP2 to CpTSP12), which were identified by using bioinformatic tools. Those authors showed that CpTSP8 is located at the apical complex of sporozoites and merozoites and is translocated onto the parasite surface, as is typical of MICs. Therefore, CpTSP8 was renamed CpMIC1. MIC proteins have been shown to be essential for host cell attachment/invasion and gliding motility (224).

gp900, gp40, gp15, Cpa135, Cp2, P23, and TRAP-C1 (Table 2) have or are predicted to have mucin-type O-glycosylation, suggesting that this type of posttranslational modification is common in proteins involved in attachment and invasion (133). Because mucin-like proteins were shown to be important for host-parasite interactions for Cryptosporidium, O'Connor and colleagues (193) undertook data mining of the Cryptosporidium genome databases to identify other mucin-like genes. They discovered a single locus of seven small mucin sequences (CpMucl to CpMuc7), which were expressed throughout the intracellular development stages. Specific antibodies inhibited infection in vitro, which is consistent with a role in host cell invasion.

The proteolytic processing of surface and apical complex proteins by parasite proteases has been shown to be required for the invasion of host cells and for egress from them. Further effort was focused on the identification of Cryptosporidium proteases. Wanyiri and colleagues (191) characterized a C. parvum subtili- sin-like serine protease (CpSUB) and showed that this protein is likely to be responsible for the processing of gp40/15 (Table 2).

The identification of these molecules that mediate attachment to and invasion of epithelial intestinal cells (as shown in Fig. 2) is advancing our understanding of the cell biology of Cryptosporidium infection (219). These proteins have features in common with other apicomplexan proteins implicated in mediating host cell interactions and are expressed on the surface of the invasive $C$. parvum sporozoite and merozoite stages and shed in trails by gliding zoites $(79,171)$. The relative contribution of each individual molecule remains to be determined. It is likely that by using a large number of seemingly redundant adhesive molecules, the parasite can maximize the opportunity for cell attachment across a broad range of potential hosts. It is also possible that quantitative or qualitative differences in these glycoproteins may confer selectivity for host attachment (13).

\section{Cellular Damage}

Cell damage in enterocyte monolayers has been documented through the disruption of tight cell junctions, a loss of barrier function, the release of lactate dehydrogenase, and increased rates of cell death (225). The mechanisms that cause cellular damage during Cryptosporidium infection remain unknown; however, several molecules can cause direct tissue damage, such as phospholipases, proteases, and hemolysins (13).

Proteases have important functions in a parasite's life cycle, such as mediating protein degradation, the invasion of host tissues, and the evasion of host immunity (226-228). Distinct protease activities have been identified for Cryptosporidium sporozoites: aminopeptidase, cysteine protease, and serine protease activities have been implicated in the excystation process (169, $189,229)$. The identification of functional proteases in sporozoites during excystation and the prevention of infection in the presence 
of protease inhibitors suggest that proteases are important in the initial stages of Cryptosporidium infection (13).

Hemolysin $\mathrm{H} 4$ has been identified by the screening of a C. parvum expression library on sheep blood agar (183). H4 has sequence similarity to the hemolysin of enterohemorrhagic Escherichia coli $\mathrm{O} 157: \mathrm{H} 7$ (183). The function of $\mathrm{H} 4$ is unknown, but its ability to disrupt cell membranes suggests a role in cellular invasion and/or the disruption of vacuolar membranes, which would allow merozoites to exit the parasitophorous vacuole and spread to adjacent cells (13). Another Cryptosporidium protein of interest is a C. parvum ATP-binding cassette (ABC) transporter gene (CpABC) localized in proximity to the electron-dense feeding organelle of the parasitophorous vacuole (184), which may well be associated with meeting key nutritional requirements. Interestingly, these genetic elements share structural similarities with bacterial genes, which are critical in producing secretory diarrhea (13).

\section{Heat Shock Proteins}

Heat shock proteins (HSPs) are a family of large conserved proteins. They are usually defined by their apparent molecular weights determined by sodium dodecyl sulfate-polyacrylamide gel electrophoresis (SDS-PAGE), with HSP90, HSP70, and HSP65 being common families (230). The level of synthesis of HSPs, especially HSP70, increases dramatically under stressful conditions (sudden shifts in temperature, decreased availability of nutrients, and immune attack). HSPs function as intracellular chaperones for other proteins; play an important role in protein-protein interactions; and facilitate the transport, folding, assembly, biosynthesis, and secretion of newly formed proteins (13).

For Cryptosporidium, two HSPs (HSP70 and HSP90) have been described $(187,231)$. Considerable polymorphism in the HSP70 gene has been identified and was used for genotyping purposes (232, 233). However, HSPs are under selective pressure, and their high degree of polymorphism might not reflect the genetic relationships among isolates or subtypes. For the closely related apicomplexan parasite $T$. gondii, it was demonstrated that quantitative and qualitative differences in HSP expression levels are related directly to parasite virulence $(230,234)$. High levels of expression of HSP70 were detected in virulent strains of $T$. gondii grown in mice, but little expression of HSP70 was observed in avirulent strains (235). The relationship between the level of HSP expression and Cryptosporidium virulence warrants further investigation.

\section{Contingency Genes}

Contingency genes, as opposed to conserved housekeeping genes, are highly variable (236). They are common in pathogenic microbes, including viral, bacterial, fungal, and protozoan pathogens $(237,238)$. Contingency genes are subject to spontaneous recombination rates higher than the background rate that applies to the other genes in the genome. These mutational events allow rapid switches in phenotype that are conducive to survival and proliferation in the host. In eukaryotic pathogens, these contingency genes are often associated with telomeres (239). Telomeres are prime sites for these quickly evolving genes that mediate hostparasite interactions. Examples of contingency virulence genes include the variant surface glycoprotein (VSG) in Trypanosoma brucei $(239,240)$, the var genes in Plasmodium falciparum (241), the trans-sialidases of Trypanosoma cruzi (242), the major surface gly- coproteins (MSG) of Pneumocystis carinii and Pneumocystis jirovecii (243), and the subtelomeric variable secreted proteins (SVSPs) of Theileria sp. (244).

Comparative genomic analyses of C. parvum and C. hominis isolates showed that the most highly divergent regions are located near the chromosome ends $(63,166)$. The majority of such genes either were transporters or contained predicted signal peptides (166), a result which supports a role for telomeric contingency genes in dictating host specificity. Our comparative genomic analyses of $C$. hominis and C. parvum allowed the identification of a new family of telomerically encoded Cryptosporidium proteins: the C. parvum-specific protein (Cops-1) and the C. hominis-specific protein (Chos-1) (63). Cops-1 and Chos-1 appear to be distantly related and share similar characteristics, including having a telomeric location, encoding secreted glycoproteins of $50 \mathrm{kDa}$, and containing clear but distinct internal repeats. The proteins that they encode are predicted to be highly glycosylated, as shown in Fig. 3 (165). These characteristics suggested a possible role in host-parasite interactions, and we undertook a further characterization of the Cops-1 protein. Consistent with such a role, Cops-1 appears to be a secreted protein localized to the oocyst content and sporozoite surface of C. parvum but not C. hominis (165). Additionally, sera from C. parvum-infected patients recognized a 50$\mathrm{kDa}$ protein in antigen preparations of C. parvum but not C. hominis, consistent with Cops-1 showing species-specific expression and being antigenic for patients (165).

\section{Overview of Cryptosporidium Virulence Factors}

The majority of the putative Cryptosporidium virulence factors detailed above, which mediate sporozoite attachment to and invasion of intestinal epithelial cells and the inactivation of which can prevent infection in vitro and in vivo, are common to all Cryptosporidium spp. These virulence factors were identified mostly in C. parvum. The number of Cryptosporidium species infecting humans is an ever-changing situation, and several new species/subtypes are added regularly. At the time of writing of this review, among 26 valid Cryptosporidium spp., at least 13 have been found in humans (with the most important for public health appearing to be C. hominis, C. parvum, C. cuniculus, C. canis, C. felis, and C. meleagridis). Of the $>60$ Cryptosporidium genotypes described, an increasing number are being identified in humans, including horse, monkey, skunk, and chipmunk genotypes, although it is uncertain if they are pathogenic. The virulence factors in humaninfective Cryptosporidium species/genotypes other than C.parvum require investigation.

In addition to interspecies differences in virulence, there have been reports of intraspecies and interisolate virulence variability. Widmer and colleagues showed that C. parvum and C. hominis strains isolated from AIDS patients showed lower virulence than the GCH1 reference isolate in terms of the release of lactate dehydrogenase and the decrease in transmonolayer resistance (245). Okhuysen and colleagues used the $50 \%$ infective dose $\left(\mathrm{ID}_{50}\right)$ as a measure of virulence for three C. parvum isolates in healthy volunteers and showed that the $\mathrm{ID}_{50}$ values were 9,87 , and 1,042 for strains TAMU, Iowa, and UCP, respectively (145). In addition, strain TAMU was the most virulent when the attack rate (clinical severity) and duration of diarrhea in humans were considered ( $86 \%$ and $94.5 \mathrm{~h}$, respectively). Those authors associated this high level of virulence with fewer calf passages than the other two strains (with significantly higher passage rates). 
A

C. parvum karyotype and cops-1 position

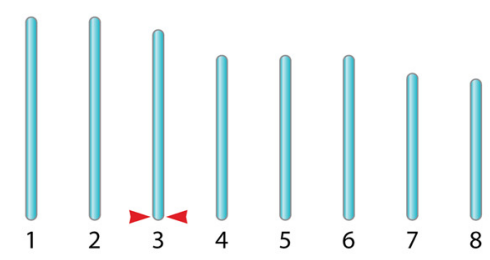

C. hominis karyotype and chos-1 position

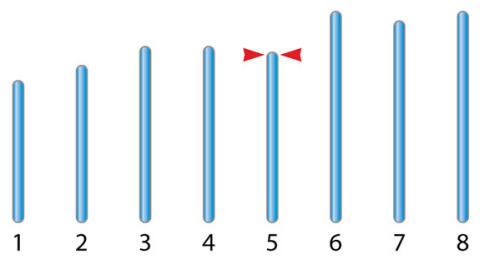

$>$ CDG2 4380 - COPS-

(477 aa; 50 Kdal; IEP 11.31)

MGNSLNVFFAIFLVVFLNF LGLQTFFNTRNVESNLFLILNSYPSFI KLGGINGREGSSSG FSSGGRHGSLQGGSLRDSARSRGGPRCSRAPHPRLQTIIECSETDSTDGGSNTASQPNGR FLNPGYGSRPGSTRGPTLGLETRSRPVEPTRRPYSGILLTSSGSKSSALSSRFGQKPSSS HSTSTGTRALQSGVGSRFLSPGYGSRPGSTRGPTLGLETRSRPVFPTRRPYSGSLFTSSS FRSSNASDGSGDSSYSSRFTGTGTRGSQGGVGSRFLSPGYGLQPGSARGPTLGLFTRSRP PLPTRKPYSGSLLTSSRLSSSNASGGLGQSSSSSRFTSTGPQGPYGISGVGTPLGHSVSP EGKPQGLLARGYITSNCPRG I PGEHRVDVT SNGSLICCYCYNRCDHEGEKPPRRT'TTTTT QSPPYSSRGYLTLDCPLGTPGEHRLDVDNSGVLFCATCGNRFSHQGCPPPKI PLCRK

>Chro.50011 - Chos-1

(489 aa; 54 Kdal; IEP 10.26)

MVRKRGIFCTLLSVVALFNDLNTDLLPKDRNLSFYFSFYLDNWSLVKLKAIGRNKNS ILT SSGSQSNVDSGPLNDGIQYQSSEEKLSDLTSRSGSAVNFGQYQDNKKF IFPGF SDFHPEP CLADPSRTHPVYVNKLGERAINCLKCEHKFNQQTHSDYSSSCKFETCKYSKPDIHLTRSC SNGCKLIFCSSCHENSDSKLSSGNSSGFECPKDEPGSNSRLARPAIKTGGASSRGGENTD FVHTPKCYFTTCCPKSSSVDFRLKVSKDNSVVCASCNNLLRHGIYDPPMSSSSSGSTSSS LRKCFNSCSVSTPVSASLTVLRPIVLKPPVPALPPRRQVTRLKLRTSQTPSTVPLPKCPG LRGGENAGFVPTPKGYFTTCCPKSSSVDFRLKVS KDNSVVCASCDNLLRHGIYDPPMSSS SSGSTNSLIRQRSRSRSRSRSRSSSRSSSRSRSRSRSRSRSRSRSHSHSHSHSHSNIESR QHQHSGPRN
$\mathrm{N}$-terminal leader sequence (NLS)

Circa 70 aa repeat sequence

Circa 20 aa repeat sequence

Tandem repeats

Putative sites of $\mathrm{N}$-linked glycosylation

Putative sites of O-linked glycosylation

FIG 3 Characteristics of the new family of telomeric Cryptosporidium proteins, Cops-1 and Chos-1. (A) Genomic positions of the Cops-1 and Chos- 1 genes. (B) Predicted Cops- 1 and Chos- 1 proteins are $50 \mathrm{kDa}$, secreted, and serine rich; contain internal repeats; and are highly glycosylated. aa, amino acids; IEP, isoelectric point. (Modified from reference 165, which was published under a Creative Commons license.)

Which genetic determinants dictate the virulence and host range of Cryptosporidium species and genotypes and by what specific mechanisms are not yet clear, and much work remains to be done. An improved picture of the composite biology of Cryptosporidium virulence factors is desirable and necessary in order to advance our understanding of the pathogenesis, host tropism, evolution, and epidemiology of Cryptosporidium species.

\section{HOST FACTORS AND CRYPTOSPORIDIUM VIRULENCE}

Host factors are critical determinants of the outcomes of hostpathogen interactions. It has been demonstrated that the severity of Cryptosporidium infection is highly dependent on host factors. The host immune capacity is the most important host factor affecting both the probability of an infection and the severity of the subsequent disease. This observation is most obvious when considering the impact of immune suppression on disease courses. Petry and colleagues (246) presented a comprehensive review of both innate and adaptive host immune responses to C. parvum infection. As the relevance and individual contribution of each of these responses remain unclear, the effect of any particular immunosuppressive disorder on the severity of Cryptosporidium infection remains difficult to predict (246). What is clear, however, is the link between an increased severity of disease and certain types of immune suppression. Indeed, many of the earliest-identified cases of human cryptosporidiosis were immunosuppressed individuals (33).

The severity of illness depends on the degree of the immunocompromised status $(43,57,60,61,72)$. In immune-suppressed subjects, cryptosporidiosis is no longer self-limiting and can be life-threatening $(43,57,58)$. However, not all forms of immune suppression lead to an increased disease severity of cryptosporidiosis. The main risk seems to be immune-suppressive disorders that impact $\mathrm{T}$ cell function, the most obvious being HIV/AIDS (60). In AIDS patients, the most severe disease occurs in people with a CD4 cell count of less than 50. Flanigan and colleagues reported that in AIDS patients, self-limited cryptosporidiosis was seen in patients with higher CD4 counts (247). Further support for the role of $\mathrm{T}$ cell function was shown by improvements in the symptoms of cryptosporidiosis following treatment with highly active antiretroviral therapy (HAART) (248).

Of the primary immune deficiencies, those diseases that have been most clearly linked to an increased severity of cryptosporidiosis have included severe combined immunodeficiency syndrome (249), X-linked hyperimmunoglobulin M syndrome $(250,251)$, and CD4 lymphopenia (252). All three of these deficiencies are also characterized by impaired $\mathrm{T}$ cell function (253). In contrast, immune deficiencies affecting $B$ cell function have not been so associated, although one report linked chronic intractable diarrhea and significant weight loss associated with cryptosporidiosis in an infant with a gamma interferon deficiency (254). There is also evidence that patients with malignant disease may also be more susceptible to infection, especially following bone marrow transplantation $(60,255,256)$. However, the number of reports of Cryptosporidium in patients with malignancy is rather lower than for people living with HIV (257), probably reflecting a less common exposure in patients with malignancy than in patients with HIV infection. There have also been reports of cryptosporidiosis 


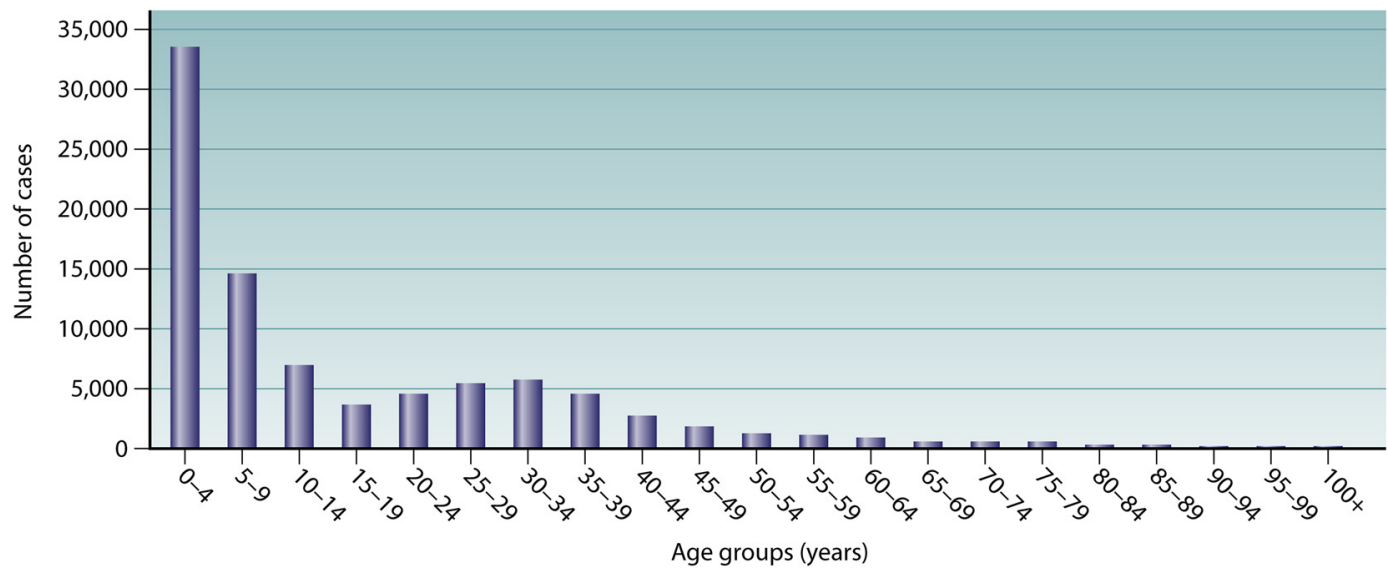

FIG 4 Total number of cryptosporidiosis cases detected in England and Wales by age group between 1989 and 2008, as reported by the Health Protection Agency (http://www.hpa.org.uk/).

in patients following solid-organ transplantation, although data were insufficient to make an adequate risk assessment $(60,255)$.

Acquired immunity would also appear to be important in preventing illness, as illustrated by reports of waterborne outbreaks of disease. During one such outbreak in Talent, OR, symptomatic cases of cryptosporidiosis occurred only in visitors to the town and not in residents, suggesting that residents had acquired immunity from previous exposures (258). For another outbreak, it was shown that swimming in a pool (a known risk factor) was negatively associated with disease in a drinking water-associated outbreak (259). One study showed that people with high anticryptosporidial antibody levels (IgG) were less likely to report diarrhea (260). What remains unclear is the duration of such acquired immunity. Evidence from adult human feeding experiments suggests that immunity may not last much longer than a year or so, and the protection acquired translates into less severe clinical symptoms (261). However, this is unlikely to be an all-or-nothing effect, as it appears that immunity merely shifts the dose-response curve to the right. In other words, even people who have acquired immunity can become ill if the ingested dose is sufficient; indeed, infection and diarrhea were reported in these subjects at a dose 20 -fold higher than that for seronegative volunteers (260). There is also some evidence that such partial immunity may give rise to symptoms even though the oocysts remained undetected in stool samples. That same study showed that oocyst shedding occurred in only $53.8 \%$ of subjects with clinical cryptosporidiosis (260).

An interesting aspect of the issues around immunity is whether regular exposure to low doses of Cryptosporidium may actually have benefit. This notion was first raised independently by Craun and colleagues (262) and Hunter and Quigley (259), who reported that attack rates were significantly higher for outbreaks associated with groundwater than surface water consumption. They argued that people who use surface water sources were regularly exposed to small numbers of oocysts and thus did not experience many outbreaks, unless there was a major breakdown in treatment. The role of immunity in modulating virulence is also supported by a risk factor analysis which identified the eating of raw vegetable as a protective factor (Table 1). Using mathematical modeling, Swift and Hunter showed how an increased probability of exposure could lead to earlier infection but reduced risk later in life (263), a hypothesis supported by data from seroepidemiology studies
(90). Indeed, if, as recently hypothesized, repeated exposure serves to maintain an otherwise short-lived immunity, there would be an optimal daily probability of exposure that would minimize illness rates; however, any increased exposure would increase the risk to the youngest individuals, who are likely to be the most vulnerable (264). In a study modeling the risk of cryptosporidiosis associated with unreliable drinking water supplies in Africa, Hunter and colleagues argued that the main impact of increased exposure would be an earlier age of first infection (265).

The age of the host is a major factor in the epidemiology of infection, with children being most at risk for cryptosporidiosis, as shown by the cumulative data for cryptosporidiosis cases detected between 1989 and 2008 (Fig. 4). Illness in children is not necessarily more or less severe than that in older age groups, although they are more likely to report vomiting. In a case-control study, 70\% of children ( $<17$ years old) reported vomiting, compared to only $46 \%$ of adults ( $>16$ years old) (P. R. Hunter, unpublished data). Infection maybe subclinical in the young, and asymptomatic carriage in children has been suggested to be an important reservoir for C. hominis infection (67). The high incidence of cryptosporidiosis in children probably reflects a lack of immunity due to few prior exposures and the immaturity of the gut mucosa $(69,72,84)$.

Of particular relevance in developing countries is the issue of malnutrition in children. Cryptosporidiosis is common in children, and it is frequently associated with persistent diarrhea, malnutrition, stunted growth, and cognitive impairment (72). There is good evidence from animal studies that cryptosporidiosis exacerbates malnutrition and that cryptosporidiosis is more severe in malnourished mice (266). For humans, the evidence also supports this synergistic relationship $(60,267)$. However, the exact mechanisms behind the increased severity of illness in malnourished children are not yet fully clear. One likely explanation is that in a malnourished child, the damage to the gut mucosa with a new Cryptosporidium infection would lead to further impaired nutrient absorption and stunting that would not be such an issue for a well-nourished child (267).

Host behavioral factors also play an important role in the variation in the risk of cryptosporidiosis by increasing or decreasing the risk of exposure to the parasite. Several such factors are discussed above and include foreign travel, contact with livestock, swimming in a swimming pool, caring for a case of infection, 
changing diapers, having multiple sexual partners, having pets, and using public toilets $(51,85,86,93,268)$. These factors are likely to affect susceptibility to infection, but they are unlikely to affect infection courses or modify clinical manifestations.

\section{HOST TROPISM AND VIRULENCE COEVOLUTION}

The consideration of genetic determinants of host tropism as a virulence factor is legitimate, as these genes would enable the parasite to adhere to and invade epithelial cells from different host species. Indeed, the presence of closely related species that infect one host species and not another is a certain indicator of the presence of virulence genes, and as discussed above, there are clear differences between host tropisms among Cryptosporidium spp. and genotypes (113). C. parvum is fairly promiscuous and can infect a range of different species, while $C$. hominis appears to infect only humans. Other Cryptosporidium spp. also have distinct host ranges that may or may not include humans. In addition, some Cryptosporidium species are considered opportunistic; indeed, unusual species were reported to infect subjects of older ages or with immune disorders (269).

Nevertheless, the exact relationships between the host range and virulence of human-infective Cryptosporidium species is not clear. The Red Queen hypothesis postulates that species continually evolve but do not become better adapted $(270,271)$, and thus, interactions between hosts and parasites lead to constant natural selection for adaptation and counteradaptation (272). Antagonistic coevolution between hosts and parasites can involve rapid fluctuations of genotype frequencies and recombination in the host, which may be advantageous and can quickly produce disproportionately fit offspring (273). It is widely held that successful parasite species should evolve to become less virulent over time, with maladapted novel parasites being initially more harmful and then attenuating (274). Considering the host ranges of C. hominis and C. parvum, the latter might be anticipated to be more virulent, allowing it to infect a wide range of species, while the former is expected to be less virulent, as postulated by the theory of hostparasite coevolution and virulence attenuation. However, Hunter and colleagues (67) showed that $C$. hominis may be associated with an increased risk of postinfectious sequelae compared to C. parvum, while Cama and colleagues (66) showed that $C$. hominis was more virulent than C. parvum and other Cryptosporidium spp. in a developing-country setting, as measured by clinical symptoms and increased oocyst shedding. Based on similar observations, Woolhouse and colleagues (10) stated that host-parasite coevolution is in principle a powerful determinant of the biology and genetics of infection and disease, which has proven difficult to demonstrate rigorously in practice. A theory on the evolution of virulence states that pathogenicity can be maintained when it is a direct or indirect consequence of the parasite's exploitation of the host (274). Thus, in certain instances, such as when tissue damage is necessary to facilitate transmission, attenuation may be prevented during parasite adaptation to the host, and virulence may even be promoted $(274,275)$. This would seem to be the case for Cryptosporidium, where in order to maximize the potential for anthropogenic transmission, coevolution results in enhanced rather than diminished virulence.

The identification of genetic determinants of host tropism in human-infective Cryptosporidium species will improve our understanding of the evolution, virulence, and epidemiology of Cryptosporidium species and will afford improvements in our abil- ity to identify and track virulent strains, particularly during outbreaks, improving opportunities for intervention. In addition, these virulence factors may well prove important as potential drug targets and vaccine candidates $(11,276)$. However, the identification and utilization of such determinants for these purposes have only just begun.

\section{CONCLUSION}

A major issue for virulence in Cryptosporidium is the difficulty in demonstrating clear phenotypic differences between many strains and species, especially in animals and cell culture. Nevertheless, by using molecular and immunological techniques, considerable advances in our knowledge of Cryptosporidium virulence and pathogenesis have been achieved recently. These advances were assisted by the publication of the genome sequences of three Cryptosporidium spp. The trans-expression of sporozoite proteins (Cpgp40/15 and P23) in the related apicomplexan parasite Toxoplasma gondii $(254,255)$ has allowed for posttranslational modifications similar to those of the native protein and showed appropriate localization and glycosylation. The expression of Cryptosporidium proteins in this genetically tractable heterologous expression system may prove to be a major advance and would certainly assist in providing an improved understanding of the functional role of several Cryptosporidium proteins. In addition, with the establishment of a unique viral transfection system, advances in Cryptosporidium cell culture (successful long-term maintenance and propagation in vitro), and high-throughput next-generation sequencing of a wide variety of strains and species, our understanding of Cryptosporidium virulence is likely to continue to improve.

As summarized in this review, there are currently over $25 \mathrm{pu}-$ tative virulence factors, identified mainly by using immunological and molecular techniques. While no virulence determinant has been unequivocally identified to date and their composite biology remains unclear, it is likely that this will change in the near future as the transfer of new technology begins to enable direct testing. On the other hand, our knowledge of certain host factors that are associated with variations in both the severity and risk of infection has increased dramatically, although the mechanisms that lie behind these observations remain for the most part to be determined.

\section{ACKNOWLEDGMENT}

We thank Dietmar Steverding for critical reading of the manuscript.

\section{REFERENCES}

1. Isenberg HD. 1988. Pathogenicity and virulence: another view. Clin. Microbiol. Rev. 1:40-53.

2. Alonso-Monge R, Navarro-García F, Román E, Eisman B, Nombela C, Pla J. 2003. Strategies for the identification of virulence determinants in human pathogenic fungi. Curr. Genet. 42:301-312.

3. Bloch H. 1950. A component of tubercle bacilli concerned with their virulence. Bull. N. Y. Acad. Med. 26:506-507.

4. Ebert D, Herre EA. 1996. The evolution of parasitic diseases. Parasitol. Today 12:96-101.

5. Garnick E. 1992. Parasite virulence and parasite-host coevolution: a reappraisal. J. Parasitol. 78:381-386.

6. Mellon R. 1926. Studies in microbic heredity. VIII. The infectivity and virulence of a filtrable phase in the life history of B. fusiformis and related organisms. J. Bacteriol. 12:279-298.

7. Pike R, Mackenzie GM. 1940. Virulence of Salmonella typhimurium. I. Analysis of experimental infection in mice with strains of high and low virulence. J. Bacteriol. 40:171-195. 
8. Poulin R, Combes C. 1999. The concept of virulence: interpretations and implications. Parasitol. Today 15:474-475.

9. Smiley H, Pearse H. 1926. Determining the virulence of positive diphtheria cultures. Am. J. Public Health (N. Y.) 16:998-1002.

10. Woolhouse ME, Webster JP, Domingo E, Charlesworth B, Levin BR. 2002. Biological and biomedical implications of the co-evolution of pathogens and their hosts. Nat. Genet. 32:569-577.

11. Casadevall A, Pirofski L. 2001. Host-pathogen interactions: the attributes of virulence. J. Infect. Dis. 184:337-344.

12. Casadevall A, Pirofski LA. 1999. Host-pathogen interactions: redefining the basic concepts of virulence and pathogenicity. Infect. Immun. 67: 3703-3713.

13. Okhuysen PC, Chappell CL. 2002. Cryptosporidium virulence determinants - are we there yet? Int. J. Parasitol. 32:517-525.

14. Fayer R, Orlandi P, Perdue ML. 2009. Virulence factor activity relationships for hepatitis E and Cryptosporidium. J. Water Health 7(Suppl 1): S55-S63. doi:10.2166/wh.2009.044.

15. Navarro-Garcia F, Sanchez M, Nombela C, Pla J. 2001. Virulence genes in the pathogenic yeast Candida albicans. FEMS Microbiol. Rev. 25:245268.

16. Edberg SC. 2009. Does the possession of virulence factor genes mean that those genes will be active? J. Water Health 7(Suppl 1):S19-S28. doi: 10.2166/wh.2009.066.

17. Karger A, Ziller M, Bettin B, Mintel B, Schares S, Geue L. 2011. Determination of serotypes of Shiga toxin-producing Escherichia coli isolates by intact cell matrix-assisted laser desorption ionization-time of flight mass spectrometry. Appl. Environ. Microbiol. 77:896-905.

18. van Asten AJ, van Dijk JE. 2005. Distribution of "classic" virulence factors among Salmonella spp. FEMS Immunol. Med. Microbiol. 44: 251-259.

19. Verstrepen KJ, Fink GR. 2009. Genetic and epigenetic mechanisms underlying cell-surface variability in protozoa and fungi. Annu. Rev. Genet. 43:1-24.

20. Goldston AM, Powell RR, Temesvari LA. 2012. Sink or swim: lipid rafts in parasite pathogenesis. Trends Parasitol. 28:417-426.

21. Butler CE, Tyler KM. 2012. Membrane traffic and synaptic cross-talk during host cell entry by Trypanosoma cruzi. Cell. Microbiol. 14:13451353.

22. Schmid-Hempel P. 2008. Parasite immune evasion: a momentous molecular war. Trends Ecol. Evol. 23:318-326.

23. Sibley LD. 2011. Invasion and intracellular survival by protozoan parasites. Immunol. Rev. 240:72-91.

24. Landfear SM. 2011. Nutrient transport and pathogenesis in selected parasitic protozoa. Eukaryot. Cell 10:483-493.

25. McKerrow JH, Caffrey C, Kelly B, Loke P, Sajid M. 2006. Proteases in parasitic diseases. Annu. Rev. Pathol. 1:497-536.

26. Ashton AW, Mukherjee S, Nagajyothi FNU, Huang H, Braunstein VL, Desruisseaux MS, Factor SM, Lopez L, Berman JW, Wittner M, Scherer PE, Capra V, Coffman TM, Serhan CN, Gotlinger K, Wu KK, Weiss LM, Tanowitz HB. 2007. Thromboxane A(2) is a key regulator of pathogenesis during Trypanosoma cruzi infection. J. Exp. Med. 204: 929-940.

27. Dean S, Marchetti R, Kirk K, Matthews KR. 2009. A surface transporter family conveys the trypanosome differentiation signal. Nature 459:213 217.

28. McClelland E, Bernhardt P, Casadevall A. 2006. Estimating the relative contributions of virulence factors for pathogenic microbes. Infect. Immun. 74:1500-1504

29. Tyzzer EE. 1907. A sporozoan found in the peptic glands of the common mouse. Proc. Soc. Exp. Biol. Med. 5:12-13.

30. Tyzzer EE. 1912. Cryptosporidium parvum (sp. nov.), a coccidium found in the small intestine of the common mouse. Arch. Protistenkd. 26:394-412.

31. Slavin D. 1955. Cryptosporidium meleagridis (sp. nov.). J. Comp. Pathol. 65:262-266.

32. Panciera RJ, Thomassen RW, Gardner FM. 1971. Cryptosporidial infection in a calf. Vet. Pathol. 8:479-484.

33. Current W, Garcia LS. 1991. Cryptosporidiosis. Clin. Microbiol. Rev. 4:325-358.

34. De Graaf D, Vanopdenbosch E, Ortega-Mora LM, Abbassi H, Peeters JE. 1999. A review of the importance of cryptosporidiosis in farm animals. Int. J. Parasitol. 29:1269-1287.
35. Holland R. 1990. Some infectious causes of diarrhea in young farm animals. Clin. Microbiol. Rev. 3:345-375.

36. Meuten D, Van Kruiningen HJ, Lein DH. 1974. Cryptosporidiosis in a calf. J. Am. Vet. Med. Assoc. 165:914-917.

37. Moore AC, Herwaldt BL, Craun GF, Calderon RL, Highsmith AK, Juranek DD. 1993. Surveillance for waterborne disease outbreaksUnited States, 1991-1992. MMWR CDC Surveill. Summ. 42:1-22.

38. O'Handley R, Olson ME. 2006. Giardiasis and cryptosporidiosis in ruminants. Vet. Clin. North Am. Food Anim. Pract. 22:623-643.

39. Tzipori S, Campbell I, Sherwood D, Snodgrass DR, Whitelaw A. 1980 An outbreak of calf diarrhoea attributed to cryptosporidial infection. Vet. Rec. 107:579-580.

40. Blagburn B, Lindsay DS, Giambrone JJ, Sundermann CA, Hoerr FJ. 1987. Experimental cryptosporidiosis in broiler chickens. Poult. Sci. 66: 442-449.

41. Current W, Snyder DB. 1988. Development of and serologic evaluation of acquired immunity to Cryptosporidium baileyi by broiler chickens. Poult. Sci. 67:720-729.

42. Goodwin M. 1989. Cryptosporidiosis in birds-a review. Avian Pathol. 18:365-384.

43. O'Donoghue P. 1995. Cryptosporidium and cryptosporidiosis in man and animals. Int. J. Parasitol. 25:139-195.

44. Meisel J, Perera DR, Meligro C, Rubin CE. 1976. Overwhelming watery diarrhea associated with a cryptosporidium in an immunosuppressed patient. Gastroenterology 70:1156-1160.

45. Nime F, Burek JD, Page DL, Holscher MA, Yardley JH. 1976. Acute enterocolitis in a human being infected with the protozoan Cryptosporidium. Gastroenterology 70:592-598.

46. Crawford F, Vermund SH. 1988. Human cryptosporidiosis. Crit. Rev. Microbiol. 16:113-159.

47. Current W, Reese NC, Ernst JV, Bailey WS, Heyman MB, Weinstein WM. 1983. Human cryptosporidiosis in immunocompetent and immunodeficient persons. Studies of an outbreak and experimental transmission. N. Engl. J. Med. 308:1252-1257.

48. Fayer R, Ungar BL. 1986. Cryptosporidium spp. and cryptosporidiosis. Microbiol. Rev. 50:458-483.

49. Forgacs P, Tarshis A, Ma P, Federman M, Mele L, Silverman ML, Shea JA. 1983. Intestinal and bronchial cryptosporidiosis in an immunodeficient homosexual man. Ann. Intern. Med. 99:793-794.

50. Ma P, Soave R. 1983. Three-step stool examination for cryptosporidiosis in 10 homosexual men with protracted watery diarrhea. J. Infect. Dis. 147:824-828

51. Soave R, Danner RL, Honig CL, Ma P, Hart CC, Nash T, Roberts RB. 1984. Cryptosporidiosis in homosexual men. Ann. Intern. Med. 100: 504-511.

52. Jokipii L, Pohjola S, Jokipii AM. 1983. Cryptosporidium: a frequent finding in patients with gastrointestinal symptoms. Lancet ii:358-361.

53. Tzipori S, Smith M, Birch C, Barnes G, Bishop R. 1983. Cryptosporidiosis in hospital patients with gastroenteritis. Am. J. Trop. Med. Hyg 32:931-934.

54. Karanis P, Kourenti C, Smith H. 2007. Waterborne transmission of protozoan parasites: a worldwide review of outbreaks and lessons learnt. J. Water Health 5:1-38.

55. Meinhardt P, Casemore DP, Miller KB. 1996. Epidemiologic aspects of human cryptosporidiosis and the role of waterborne transmission. Epidemiol. Rev. 18:118-136.

56. Blackburn BG, Craun GF, Yoder JS, Hill V, Calderon RL, Chen N, Lee SH, Levy DA, Beach MJ. 2004. Surveillance for waterborne-disease outbreaks associated with drinking water-United States, 2001-2002. MMWR Surveill. Summ. 53:23-45.

57. Chen X, Keithly JS, Paya CV, LaRusso NF. 2002. Cryptosporidiosis. N. Engl. J. Med. 346:1723-1731.

58. Juranek D. 1995. Cryptosporidiosis: sources of infection and guidelines for prevention. Clin. Infect. Dis. 22:S57-S61. doi:10.1093/clinids/21 Supplement_1.S57.

59. Manabe YC, Clark DP, Moore RD, Lumadue JA, Dahlman HR, Belitsos PC, Chaisson RE, Sears CL. 1998. Cryptosporidiosis in patients with AIDS: correlates of disease and survival. Clin. Infect. Dis. 27:536542 .

60. Hunter P, Nichols G. 2002. Epidemiology and clinical features of Cryptosporidium infection in immunocompromised patients. Clin. Microbiol. Rev. 15:145-154. 
61. Chalmers RM, Davies AP. 2010. Clinical cryptosporidiosis. Exp. Parasitol. 124:138-146.

62. Cacciò S. 2005. Molecular epidemiology of human cryptosporidiosis. Parassitologia 47:185-192.

63. Bouzid M, Tyler KM, Christen R, Chalmers RM, Elwin K, Hunter PR. 2010. Multi-locus analysis of human infective Cryptosporidium species and subtypes using ten novel genetic loci. BMC Microbiol. 10:213. doi: 10.1186/1471-2180-10-213.

64. Chalmers RM, Smith R, Elwin K, Clifton-Hadley FA, Giles M. 2011. Epidemiology of anthroponotic and zoonotic human cryptosporidiosis in England and Wales, 2004-2006. Epidemiol. Infect. 139:700-712.

65. Cama VA, Ross JM, Crawford S, Kawai V, Chavez-Valdez R, Vargas D, Vivar A, Ticona E, Navincopa M, Williamson J, Ortega Y, Gilman RH, Bern C, Xiao L. 2007. Differences in clinical manifestations among Cryptosporidium species and subtypes in HIV-infected persons. J. Infect. Dis. 196:684-691.

66. Cama VA, Bern C, Roberts J, Cabrera L, Sterling CR, Ortega Y, Gilman RH, Xiao L. 2008. Cryptosporidium species and subtypes and clinical manifestations in children, Peru. Emerg. Infect. Dis. 14:15671574.

67. Hunter P, Hughes S, Woodhouse S, Raj N, Syed Q, Chalmers RM, Verlander NQ, Goodacre J. 2004. Health sequelae of human cryptosporidiosis in immunocompetent patients. Clin. Infect. Dis. 39:504-510.

68. Casemore D, Sands RL, Curry A. 1985. Cryptosporidium species a "new" human pathogen. J. Clin. Pathol. 38:1321-1336.

69. Hunter P, Thompson RC. 2005. The zoonotic transmission of Giardia and Cryptosporidium. Int. J. Parasitol. 35:1181-1190.

70. Xiao L, Feng Y. 2008. Zoonotic cryptosporidiosis. FEMS Immunol. Med. Microbiol. 52:309-323.

71. Glaberman S, Moore JE, Lowery CJ, Chalmers RM, Sulaiman I, Elwin K, Rooney PJ, Millar BC, Dooley JS, Lal AA, Xiao L. 2002. Three drinking-water-associated cryptosporidiosis outbreaks, Northern Ireland. Emerg. Infect. Dis. 8:631-633.

72. Guerrant R. 1997. Cryptosporidiosis: an emerging, highly infectious threat. Emerg. Infect. Dis. 3:51-57.

73. Hayes EB, Matte TD, O'Brien TR, McKinley TW, Logsdon GS, Rose JB, Ungar BLP, Word DM, Wilson MA, Long EG, Hurwitz ES, Juranek DD. 1989. Large community outbreak of cryptosporidiosis due to contamination of a filtered public water supply. N. Engl. J. Med. 320:13721376.

74. Jiang J, Alderisio KA, Xiao L. 2005. Distribution of Cryptosporidium genotypes in storm event water samples from three watersheds in New York. Appl. Environ. Microbiol. 71:4446-4454.

75. Xiao L, Alderisio K, Limor J, Royer M, Lal AA. 2000. Identification of species and sources of Cryptosporidium oocysts in storm waters with a small-subunit rRNA-based diagnostic and genotyping tool. Appl. Environ. Microbiol. 66:5492-5498.

76. Egger M, Mäusezahl D, Odermatt P, Marti HP, Tanner M. 1990. Symptoms and transmission of intestinal cryptosporidiosis. Arch. Dis. Child. 65:445-447.

77. Harari M, West B, Dwyer B. 1986. Cryptosporidium as cause of laryngotracheitis in an infant. Lancet i:1207. doi:10.1016/S0140 -6736(86)91181-5.

78. Ma P, Villanueva TG, Kaufman D, Gillooley JF. 1984. Respiratory cryptosporidiosis in the acquired immune deficiency syndrome. Use of modified cold kinyoun and hemacolor stains for rapid diagnoses. JAMA 252:1298-1301.

79. Tzipori S, Ward H. 2002. Cryptosporidiosis: biology, pathogenesis and disease. Microbes Infect. 4:1047-1058.

80. Goldstein ST, Juranek DD, Ravenholt O, Hightower AW, Martin DG, Mesnik JL, Griffiths SD, Bryant AJ, Reich RR, Herwaldt BL. 1996. Cryptosporidiosis: an outbreak associated with drinking water despite state-of-the-art water treatment. Ann. Intern. Med. 124:459-468.

81. Kramer MH, Sorhage FE, Goldstein ST, Dalley E, Wahlquist SP, Herwaldt BL. 1998. First reported outbreak in the United States of cryptosporidiosis associated with a recreational lake. Clin. Infect. Dis. 26:27-33.

82. MacKenzie WR, Schell WL, Blair KA, Addiss DG, Peterson DE, Hoxie NJ, Kazmierczak JJ, Davis JP. 1995. Massive outbreak of waterborne cryptosporidium infection in Milwaukee, Wisconsin-recurrence of illness and risk of secondary transmission. Clin. Infect. Dis. 21:57-62.

83. McAnulty JM, Fleming DW, Gonzalez AH. 1994. A community-wide outbreak of cryptosporidiosis associated with swimming at a wave pool. JAMA 272:1597-1600.

84. Yoder JS, Beach MJ. 2010. Cryptosporidium surveillance and risk factors in the United States. Exp. Parasitol. 124:31-39.

85. Robertson B, Sinclair MI, Forbes AB, Veitch M, Kirk M, Cunliffe D, Willis J, Fairley CK. 2002. Case-control studies of sporadic cryptosporidiosis in Melbourne and Adelaide, Australia. Epidemiol. Infect. 128: 419-431.

86. Roy S, DeLong SM, Stenzel SA, Shiferaw B, Roberts JM, Khalakdina A, Marcus R, Segler SD, Shah DD, Thomas S, Vugia DJ, Zansky SM, Dietz V, Beach MJ, Emerging Infections Program FoodNet Working Group. 2004. Risk factors for sporadic cryptosporidiosis among immunocompetent persons in the United States from 1999 to 2001. J. Clin. Microbiol. 42:2944-2951.

87. Goh S, Reacher M, Casemore DP, Verlander NQ, Chalmers R, Knowles M, Williams J, Osborn K, Richards S. 2004. Sporadic cryptosporidiosis, North Cumbria, England, 1996-2000. Emerg. Infect. Dis. 10:1007-1015.

88. Pintar KD, Pollari F, Waltner-Toews D, Charron DF, McEwen SA, Fazil A, Nesbitt A. 2009. A modified case-control study of cryptosporidiosis (using non-Cryptosporidium-infected enteric cases as controls) in a community setting. Epidemiol. Infect. 137:1789-1799.

89. Valderrama AL, Hlavsa MC, Cronquist A, Cosgrove S, Johnston SP, Roberts JM, Stock ML, Xiao L, Xavier K, Beach MJ. 2009. Multiple risk factors associated with a large statewide increase in cryptosporidiosis. Epidemiol. Infect. 137:1781-1788.

90. Frost FJ, Roberts M, Kunde TR, Craun G, Tollestrup K, Harter L, Muller T. 2005. How clean must our drinking water be: the importance of protective immunity. J. Infect. Dis. 191:809-814.

91. Colford JM, Jr, Saha SR, Wade TJ, Wright CC, Vu M, Charles S, Jensen P, Hubbard A, Levy DA, Eisenberg JN. 2005. A pilot randomized, controlled trial of an in-home drinking water intervention among HIV+ persons. J. Water Health 3:173-184.

92. Dwivedi KK, Prasad G, Saini S, Mahajan S, Lal S, Baveja UK. 2007. Enteric opportunistic parasites among HIV infected individuals: associated risk factors and immune status. Jpn. J. Infect. Dis. 60:76-81.

93. Hellard M, Hocking J, Willis J, Dore G, Fairley C. 2003. Risk factors leading to Cryptosporidium infection in men who have sex with men. Sex. Transm. Infect. 79:412-414.

94. Becher KA, Robertson ID, Fraser DM, Palmer DG, Thompson RC. 2004. Molecular epidemiology of Giardia and Cryptosporidium infections in dairy calves originating from three sources in Western Australia. Vet. Parasitol. 123:1-9.

95. Horman A, Korpela H, Sutinen J, Wedel H, Hanninen ML. 2004. Meta-analysis in assessment of the prevalence and annual incidence of Giardia spp. and Cryptosporidium spp. infections in humans in the Nordic countries. Int. J. Parasitol. 34:1337-1346.

96. Nimri L, Batchoun R. 1994. Prevalence of Cryptosporidium species in elementary school children. J. Clin. Microbiol. 32:1040-1042.

97. Okafor JI, Okunji PO. 1996. Prevalence of Cryptosporidium oocysts in faecal samples of some school children in Enugu State, Nigeria. J. Commun. Dis. 28:49-55.

98. Wallis PM, Erlandsen SL, Isaac-Renton JL, Olson ME, Robertson WJ, van Keulen H. 1996. Prevalence of Giardia cysts and Cryptosporidium oocysts and characterization of Giardia spp. isolated from drinking water in Canada. Appl. Environ. Microbiol. 62:2789-2797.

99. Blanco MA, Iborra A, Vargas A, Nsie E, Mba L, Fuentes I. 2009. Molecular characterization of Cryptosporidium isolates from humans in Equatorial Guinea. Trans. R. Soc. Trop. Med. Hyg. 103:1282-1284.

100. Leoni F, Amar C, Nichols G, Pedraza-Díaz S, McLauchlin J. 2006. Genetic analysis of Cryptosporidium from 2414 humans with diarrhoea in England between 1985 and 2000. J. Med. Microbiol. 55:703-707.

101. Mueller-Doblies D, Giles M, Elwin K, Smith RP, Clifton-Hadley FA, Chalmers RM. 2008. Distribution of Cryptosporidium species in sheep in the UK. Vet. Parasitol. 154:214-219.

102. Brook EJ, Anthony Hart C, French NP, Christley RM. 2009. Molecular epidemiology of Cryptosporidium subtypes in cattle in England. Vet. J. 179:378-382.

103. Chalmers R, Hadfield SJ, Jackson CJ, Elwin K, Xiao L, Hunter P. 2008. Geographic linkage and variation in Cryptosporidium hominis. Emerg. Infect. Dis. 14:496-498.

104. Geurden T, Levecke B, Caccio SM, Visser A, De Groote G, Casaert S, Vercruysse J, Claerebout E. 2009. Multilocus genotyping of Cryptospo- 
ridium and Giardia in non-outbreak related cases of diarrhoea in human patients in Belgium. Parasitology 136:1161-1168.

105. Hunter P, Hadfield SJ, Wilkinson D, Lake IR, Harrison FC, Chalmers RM. 2007. Subtypes of Cryptosporidium parvum in humans and disease risk. Emerg. Infect. Dis. 13:82-88.

106. Xiao L, Hlavsa MC, Yoder J, Ewers C, Dearen T, Yang W, Nett R, Harris S, Brend SM, Harris M, Onischuk L, Valderrama AL, Cosgrove S, Xavier K, Hall N, Romero S, Young S, Johnston SP, Arrowood M, Roy S, Beach MJ. 2009. Subtype analysis of Cryptosporidium specimens from sporadic cases in Colorado, Idaho, New Mexico, and Iowa in 2007: widespread occurrence of one Cryptosporidium hominis subtype and case history of an infection with the Cryptosporidium horse genotype. J. Clin. Microbiol. 47:3017-3020.

107. Zintl A, Proctor AF, Read C, Dewaal T, Shanaghy N, Fanning S, Mulcahy G. 2009. The prevalence of Cryptosporidium species and subtypes in human faecal samples in Ireland. Epidemiol. Infect. 137:270277.

108. Alves M, Xiao L, Antunes F, Matos O. 2006. Distribution of Cryptosporidium subtypes in humans and domestic and wild ruminants in Portugal. Parasitol. Res. 99:287-292.

109. Leav B, Mackay MR, Anyanwu A, O'Connor RM, Cevallos AM, Kindra G, Rollins NC, Bennish ML, Nelson RG, Ward HD. 2002. Analysis of sequence diversity at the highly polymorphic Cpgp40/15 locus among Cryptosporidium isolates from human immunodeficiency virus-infected children in South Africa. Infect. Immun. 70:3881-3890.

110. Fayer R, Morgan U, Upton SJ. 2000. Epidemiology of Cryptosporidium: transmission, detection and identification. Int. J. Parasitol. 30: $1305-1322$

111. Ramirez N, Ward LA, Sreevatsan S. 2004. A review of the biology and epidemiology of cryptosporidiosis in humans and animals. Microbes Infect. 6:773-785.

112. Tzipori S, Widmer G. 2008. A hundred-year retrospective on cryptosporidiosis. Trends Parasitol. 24:184-189.

113. Xiao L, Fayer R. 2008. Molecular characterisation of species and genotypes of Cryptosporidium and Giardia and assessment of zoonotic transmission. Int. J. Parasitol. 38:1239-1255.

114. Xiao L. 2010. Molecular epidemiology of cryptosporidiosis: an update. Exp. Parasitol. 124:80-89.

115. Jex AR, Smith HV, Monis PT, Campbell BE, Gasser RB. 2008. Cryptosporidium - biotechnological advances in the detection, diagnosis and analysis of genetic variation. Biotechnol. Adv. 26:304-317.

116. Chalmers RM, Campbell B, Crouch N, Davies AP. 2010. Clinical laboratory practices for detection and reporting of Cryptosporidium in community cases of diarrhoea in the United Kingdom, 2008. Euro Surveill. 15(48):pii=19731. http://www.eurosurveillance.org /ViewArticle.aspx?ArticleId = 19731

117. Bouzid M, Steverding D, Tyler KM. 2008. Detection and surveillance of waterborne protozoan parasites. Curr. Opin. Biotechnol. 19:302-306.

118. Bruijnesteijn van Coppenraet LES, Wallinga JA, Ruijs GJHM, Bruins MJ, Verweij JJ. 2009. Parasitological diagnosis combining an internally controlled real-time PCR assay for the detection of four protozoa in stool samples with a testing algorithm for microscopy. Clin. Microbiol. Infect. 15:869-874.

119. Laxer MA, Timblin BK, Patel RJ. 1991. DNA sequences for the specific detection of Cryptosporidium parvum by the polymerase chain reaction. Am. J. Trop. Med. Hyg. 45:688-694.

120. Amar CFL, East CL, Gray J, Iturriza-Gomara M, Maclure EA, McLauchlin J. 2007. Detection by PCR of eight groups of enteric pathogens in 4,627 faecal samples: re-examination of the English case-control Infectious Intestinal Disease Study (1993-1996). Eur. J. Clin. Microbiol. Infect. Dis. 26:311-323.

121. Chalmers RM, Campbell BM, Crouch N, Charlett A, Davies AP. 2011. Comparison of diagnostic sensitivity and specificity of seven Cryptosporidium assays used in the UK. J. Med. Microbiol. 60:1598-1604.

122. Davies AP, Chalmers RM. 2009. Cryptosporidiosis. BMJ 339:b4168. doi:10.1136/bmj.b4168.

123. Widmer G, Sullivan S. 2012. Genomics and population biology of Cryptosporidium species. Parasite Immunol. 34:61-71.

124. Robinson G, Chalmers RM. 2012. Assessment of polymorphic genetic markers for multi-locus typing of Cryptosporidium parvum and Cryptosporidium hominis. Exp. Parasitol. 132:200-215.

125. Barta JR, Thompson RC. 2006. What is Cryptosporidium? Reappraising its biology and phylogenetic affinities. Trends Parasitol. 22:463-468.
126. Thompson RC, Olson ME, Zhu G, Enomoto S, Abrahamsen MS, Hijjawi NS. 2005. Cryptosporidium and cryptosporidiosis. Adv. Parasitol. 59:77-158.

127. Rosales MJ, Cordon GP, Moreno MS, Sanchez CM. 2005. Extracellular like-gregarine stages of Cryptosporidium parvum. Acta Trop. 95:74-78.

128. Fayer R, Leek RG. 1984. The effects of reducing conditions, medium, $\mathrm{pH}$, temperature, and time on in vitro excystation of Cryptosporidium. J. Protozool. 31:567-569.

129. Reduker D, Speer CA. 1985. Factors influencing excystation in Cryptosporidium oocysts from cattle. J. Parasitol. 71:112-115.

130. Robertson L, Campbell AT, Smith HV. 1993. In vitro excystation of Cryptosporidium parvum. Parasitology 106:13-19.

131. Wetzel DM, Schmidt J, Kuhlenschmidt MS, Dubey JP, Sibley LD. 2005. Gliding motility leads to active cellular invasion by Cryptosporidium parvum sporozoites. Infect. Immun. 73:5379-5387.

132. Chen XM, O'Hara SP, Huang BQ, Nelson JB, Lin JJ, Zhu G, Ward HD, LaRusso NF. 2004. Apical organelle discharge by Cryptosporidium parvum is temperature, cytoskeleton, and intracellular calcium dependent and required for host cell invasion. Infect. Immun. 72:6806-6816.

133. Wanyiri J, Ward H. 2006. Molecular basis of Cryptosporidium-host cell interactions: recent advances and future prospects. Future Microbiol. 1:201-208.

134. Tetley L, Brown SM, McDonald V, Coombs GH. 1998. Ultrastructural analysis of the sporozoite of Cryptosporidium parvum. Microbiology 144(Part 12):3249-3255.

135. Boulter-Bitzer J, Lee H, Trevors JT. 2007. Molecular targets for detection and immunotherapy in Cryptosporidium parvum. Biotechnol. Adv. 25:13-44.

136. Bonnin A, Dubremetz JF, Camerlynck P. 1993. A new antigen of Cryptosporidium parvum micronemes possessing epitopes crossreactive with macrogamete granules. Parasitol. Res. 79:8-14.

137. Petersen C, Gut J, Doyle PS, Crabb JH, Nelson RG, Leech JH. 1992. Characterization of a $>900,000-\mathrm{M}(\mathrm{r})$ Cryptosporidium parvum sporozoite glycoprotein recognized by protective hyperimmune bovine colostral immunoglobulin. Infect. Immun. 60:5132-5138.

138. Tomley FM, Soldati DS. 2001. Mix and match modules: structure and function of microneme proteins in apicomplexan parasites. Trends Parasitol. 17:81-88.

139. Göbel E, Brändler U. 1982. Ultrastructure of microgametogenesis, microgametes and gametogony of Cryptosporidium sp. in the small intestine of mice. Protistologica 18:331-344.

140. Smith H, Rose JB. 1998. Waterborne cryptosporidiosis: current status. Parasitol. Today 14:14-22.

141. Current W, Reese NC. 1986. A comparison of endogenous development of three isolates of Cryptosporidium in suckling mice. J. Protozool. 33: 98-108.

142. Siński E, Behnke JM. 2004. Apicomplexan parasites: environmental contamination and transmission. Pol. J. Microbiol. 53:67-73.

143. DuPont H, Chappell CL, Sterling CR, Okhuysen PC, Rose JB, Jakubowski W. 1995. The infectivity of Cryptosporidium parvum in healthy volunteers. N. Engl. J. Med. 332:855-859.

144. Jokipii L, Jokipii AM. 1986. Timing of symptoms and oocyst excretion in human cryptosporidiosis. N. Engl. J. Med. 315:1643-1647.

145. Okhuysen PC, Chappell CL, Crabb JH, Sterling CR, DuPont HL. 1999. Virulence of three distinct Cryptosporidium parvum isolates for healthy adults. J. Infect. Dis. 180:1275-1281.

146. Blunt D, Khramtsov NV, Upton SJ, Montelone BA. 1997. Molecular karyotype analysis of Cryptosporidium parvum: evidence for eight chromosomes and a low-molecular-size molecule. Clin. Diagn. Lab. Immunol. 4:11-13.

147. Hays M, Mosier DA, Oberst RD. 1995. Enhanced karyotype resolution of Cryptosporidium parvum by contour-clamped homogeneous electric fields. Vet. Parasitol. 58:273-280.

148. Khramtsov N, Woods KM, Nesterenko MV, Dykstra CC, Upton SJ. 1997. Virus-like, double-stranded RNAs in the parasitic protozoan Cryptosporidium parvum. Mol. Microbiol. 26:289-300.

149. Clark D. 1999. New insights into human cryptosporidiosis. Clin. Microbiol. Rev. 12:554-563.

150. Le Blancq S, Khramtsov NV, Zamani F, Upton SJ, Wu TW. 1997. Ribosomal RNA gene organization in Cryptosporidium parvum. Mol. Biochem. Parasitol. 90:463-478.

151. LaGier M, Tachezy J, Stejskal F, Kutisova K, Keithly JS. 2003. Mitochondrial-type iron-sulfur cluster biosynthesis genes (IscS and IscU) in 
the apicomplexan Cryptosporidium parvum. Microbiology 149:35193530.

152. Zhu G, Marchewka MJ, Keithly JS. 2000. Cryptosporidium parvum appears to lack a plastid genome. Microbiology 146:315-321.

153. Abrahamsen M, Templeton TJ, Enomoto S, Abrahante JE, Zhu G, Lancto CA, Deng M, Liu C, Widmer G, Tzipori S, Buck GA, Xu P, Bankier AT, Dear PH, Konfortov BA, Spriggs HF, Iyer L, Anantharaman V, Aravind L, Kapur V. 2004. Complete genome sequence of the apicomplexan, Cryptosporidium parvum. Science 304:441-445.

154. Xu P, Widmer G, Wang Y, Ozaki LS, Alves JM, Serrano MG, Puiu D, Manque P, Akiyoshi D, Mackey AJ, Pearson WR, Dear PH, Bankier AT, Peterson DL, Abrahamsen MS, Kapur V, Tzipori S, Buck GA. 2004. The genome of Cryptosporidium hominis. Nature 431:1107-1112.

155. Widmer G, Carlton JM, Silva JC, London E. 2007. The Cryptosporidium muris genome project: a progress report, abstr 114. Abstr. 2nd Int. Giardia Cryptosporidium Conf., Morelia, Michoacan, Mexico, 13 to 18 May 2007.

156. Rider SD, Jr, Zhu G. 2010. Cryptosporidium: genomic and biochemical features. Exp. Parasitol. 124:2-9.

157. Pain A, Crossman L, Parkhill J. 2005. Comparative apicomplexan genomics. Nat. Rev. Microbiol. 3:454-455.

158. Keithly J, Langreth SG, Buttle KF, Mannella CA. 2005. Electron tomographic and ultrastructural analysis of the Cryptosporidium parvum relict mitochondrion, its associated membranes, and organelles. J. Eukaryot. Microbiol. 52:132-140.

159. Puiu D, Enomoto S, Buck GA, Abrahamsen MS, Kissinger JC. 2004. CryptoDB: the Cryptosporidium genome resource. Nucleic Acids Res. 32:D329-D331. doi:10.1093/nar/gkh050.

160. Striepen B, Kissinger JC. 2004. Genomics meets transgenics in search of the elusive Cryptosporidium drug target. Trends Parasitol. 20:355-358.

161. Templeton T, Iyer LM, Anantharaman V, Enomoto S, Abrahante JE, Subramanian GM, Hoffman SL, Abrahamsen MS, Aravind L. 2004. Comparative analysis of apicomplexa and genomic diversity in eukaryotes. Genome Res. 14:1686-1695.

162. Gordon JL, Sibley LD. 2005. Comparative genome analysis reveals a conserved family of actin-like proteins in apicomplexan parasites. BMC Genomics 6:179. doi:10.1186/1471-2164-6-179.

163. Nagamune K, Sibley LD. 2006. Comparative genomic and phylogenetic analyses of calcium ATPases and calcium-regulated proteins in the apicomplexa. Mol. Biol. Evol. 23:1613-1627.

164. Kuo C, Wares JP, Kissinger JC. 2008. The apicomplexan whole-genome phylogeny: an analysis of incongruence among gene trees. Mol. Biol. Evol. 25:2689-2698.

165. Bouzid M, Hunter PR, McDonald V, Elwin K, Chalmers RM, Tyler KM. 2012. A new heterogeneous family of telomerically encoded Cryptosporidium proteins. Evol. Appl. doi:10.1111/j.1752-4571.2012.00277.x.

166. Widmer G, Lee Y, Hunt P, Martinelli A, Tolkoff M, Bodi K. 2012. Comparative genome analysis of two Cryptosporidium parvum isolates with different host range. Infect. Genet. Evol. 12:1213-1221.

167. Snelling WJ, Lin Q, Moore JE, Millar BC, Tosini F, Pozio E, Dooley JS, Lowery CJ. 2007. Proteomics analysis and protein expression during sporozoite excystation of Cryptosporidium parvum (Coccidia, Apicomplexa). Mol. Cell. Proteomics 6:346-355.

168. Artz JD, Wernimont AK, Allali-Hassani A, Zhao Y, Amani M, Lin YH, Senisterra G, Wasney GA, Fedorov O, King O, Roos A, Lunin VV, Qiu W, Finerty P, Jr, Hutchinson A, Chau I, von Delft F, Mackenzie F, Lew J, Kozieradzki I, Vedadi M, Schapira M, Zhang C, Shokat K, Heightman T, Hui R. 2011. The Cryptosporidium parvum kinome. BMC Genomics 12:478. doi:10.1186/1471-2164-12-478.

169. Okhuysen PC, Chappell CL, Kettner C, Sterling CR. 1996. Cryptosporidium parvum metalloaminopeptidase inhibitors prevent in vitro excystation. Antimicrob. Agents Chemother. 40:2781-2784.

170. Riggs MW, Stone AL, Yount PA, Langer RC, Arrowood MJ, Bentley DL. 1997. Protective monoclonal antibody defines a circumsporozoitelike glycoprotein exoantigen of Cryptosporidium parvum sporozoites and merozoites. J. Immunol. 158:1787-1795.

171. Strong W, Gut J, Nelson RG. 2000. Cloning and sequence analysis of a highly polymorphic Cryptosporidium parvum gene encoding a 60 kilodalton glycoprotein and characterization of its 15- and 45-kilodalton zoite surface antigen products. Infect. Immun. 68:4117-4134.

172. Cevallos A, Zhang X, Waldor MK, Jaison S, Zhou X, Tzipori S, Neutra MR, Ward HD. 2000. Molecular cloning and expression of a gene en- coding Cryptosporidium parvum glycoproteins gp40 and gp15. Infect. Immun. 68:4108-4116.

173. Cevallos AM, Bhat N, Verdon R, Hamer DH, Stein B, Tzipori S, Pereira ME, Keusch GT, Ward HD. 2000. Mediation of Cryptosporidium parvum infection in vitro by mucin-like glycoproteins defined by a neutralizing monoclonal antibody. Infect. Immun. 68:5167-5175.

174. Perryman LE, Jasmer DP, Riggs MW, Bohnet SG, McGuire TC, Arrowood MJ. 1996. A cloned gene of Cryptosporidium parvum encodes neutralization-sensitive epitopes. Mol. Biochem. Parasitol. 80: 137-147.

175. Arrowood MJ, Sterling CR, Healey MC. 1991. Immunofluorescent microscopical visualization of trails left by gliding Cryptosporidium parvum sporozoites. J. Parasitol. 77:315-317.

176. Bhat N, Joe A, PereiraPerrin M, Ward HD. 2007. Cryptosporidium p30, a galactose/ $\mathrm{N}$-acetylgalactosamine-specific lectin, mediates infection in vitro. J. Biol. Chem. 282:34877-34887.

177. Spano F, Putignani L, Naitza S, Puri C, Wright S, Crisanti A. 1998. Molecular cloning and expression analysis of a Cryptosporidium parvum gene encoding a new member of the thrombospondin family. Mol. Biochem. Parasitol. 92:147-162.

178. Nesterenko MV, Woods K, Upton SJ. 1999. Receptor/ligand interactions between Cryptosporidium parvum and the surface of the host cell. Biochim. Biophys. Acta 1454:165-173.

179. Bjorneby JM, Riggs MW, Perryman LE. 1990. Cryptosporidium parvum merozoites share neutralization-sensitive epitopes with sporozoites. J. Immunol. 145:298-304.

180. Riggs MW, McGuire TC, Mason PH, Perryman LE. 1989. Neutralization-sensitive epitopes are exposed on the surface of infectious Cryptosporidium parvum sporozoites. J. Immunol. 143:1340-1345.

181. Tosini F, Agnoli A, Mele R, Gomez Morales MA, Pozio E. 2004. A new modular protein of Cryptosporidium parvum, with ricin B and LCCL domains, expressed in the sporozoite invasive stage. Mol. Biochem. Parasitol. 134:137-147.

182. Pollok RC, McDonald V, Kelly P, Farthing MJ. 2003. The role of Cryptosporidium parvum-derived phospholipase in intestinal epithelial cell invasion. Parasitol. Res. 90:181-186.

183. Steele MI, Kuhls TL, Nida K, Meka CS, Halabi IM, Mosier DA, Elliott W, Crawford DL, Greenfield RA. 1995. A Cryptosporidium parvum genomic region encoding hemolytic activity. Infect. Immun. 63:38403845.

184. Perkins ME, Riojas YA, Wu TW, Le Blancq SM. 1999. CpABC, a Cryptosporidium parvum ATP-binding cassette protein at the hostparasite boundary in intracellular stages. Proc. Natl. Acad. Sci. U. S. A. 96:5734-5739.

185. LaGier MJ, Zhu G, Keithly JS. 2001. Characterization of a heavy metal ATPase from the apicomplexan Cryptosporidium parvum. Gene 266: 25-34.

186. LaGier MJ, Keithly JS, Zhu G. 2002. Characterisation of a novel transporter from Cryptosporidium parvum. Int. J. Parasitol. 32:877-887.

187. Khramtsov NV, Tilley M, Blunt DS, Montelone BA, Upton SJ. 1995. Cloning and analysis of a Cryptosporidium parvum gene encoding a protein with homology to cytoplasmic form Hsp70. J. Eukaryot. Microbiol. 42:416-422.

188. Zhu G, LaGier MJ, Stejskal F, Millership JJ, Cai X, Keithly JS. 2002. Cryptosporidium parvum: the first protist known to encode a putative polyketide synthase. Gene 298:79-89.

189. Nesterenko MV, Tilley M, Upton SJ. 1995. A metallo-dependent cysteine proteinase of Cryptosporidium parvum associated with the surface of sporozoites. Microbios 83:77-88.

190. Camero L, Shulaw WP, Xiao L. 2003. Characterization of a Cryptosporidium parvum gene encoding a protein with homology to long chain fatty acid synthetase. J. Eukaryot. Microbiol. 50(Suppl):534-538.

191. Wanyiri JW, Techasintana P, O'Connor RM, Blackman MJ, Kim K, Ward HD. 2009. Role of CpSUB1, a subtilisin-like protease, in Cryptosporidium parvum infection in vitro. Eukaryot. Cell 8:470-477.

192. Putignani L, Possenti A, Cherchi S, Pozio E, Crisanti A, Spano F. 2008. The thrombospondin-related protein CpMIC1 (CpTSP8) belongs to the repertoire of micronemal proteins of Cryptosporidium parvum. Mol. Biochem. Parasitol. 157:98-101.

193. O'Connor RM, Burns PB, Ha-Ngoc T, Scarpato K, Khan W, Kang G, Ward H. 2009. Polymorphic mucin antigens CpMuc4 and CpMuc5 are integral to Cryptosporidium parvum infection in vitro. Eukaryot. Cell 8:461-469. 
194. Langer RC, Riggs MW. 1999. Cryptosporidium parvum apical complex glycoprotein CSL contains a sporozoite ligand for intestinal epithelial cells. Infect. Immun. 67:5282-5291.

195. Schaefer DA, Auerbach-Dixon BA, Riggs MW. 2000. Characterization and formulation of multiple epitope-specific neutralizing monoclonal antibodies for passive immunization against cryptosporidiosis. Infect. Immun. 68:2608-2616.

196. Langer RC, Schaefer DA, Riggs MW. 2001. Characterization of an intestinal epithelial cell receptor recognized by the Cryptosporidium parvum sporozoite ligand CSL. Infect. Immun. 69:1661-1670.

197. Barnes DA, Bonnin A, Huang JX, Gousset L, Wu J, Gut J, Doyle P, Dubremetz JF, Ward H, Petersen C. 1998. A novel multi-domain mucin-like glycoprotein of Cryptosporidium parvum mediates invasion. Mol. Biochem. Parasitol. 96:93-110.

198. Bonnin A, Ojcius DM, Souque P, Barnes DA, Doyle PS, Gut J, Nelson RG, Petersen C, Dubremetz JF. 2001. Characterization of a monoclonal antibody reacting with antigen-4 domain of gp900 in Cryptosporidium parvum invasive stages. Parasitol. Res. 87:589-592.

199. Petersen C, Barnes DA, Gousset L. 1997. Cryptosporidium parvum GP900, a unique invasion protein. J. Eukaryot. Microbiol. 44:89S-90S. doi:10.1111/j.1550-7408.1997.tb05802.x.

200. Sulaiman I, Lal AA, Xiao L. 2001. A population genetic study of the Cryptosporidium parvum human genotype parasites. J. Eukaryot. Microbiol. 2001(Suppl):24S-27S. doi:10.1111/j.1550-7408.2001.tb00441.x.

201. Alves M, Xiao L, Sulaiman I, Lal AA, Matos O, Antunes F. 2003. Subgenotype analysis of Cryptosporidium isolates from humans, cattle, and zoo ruminants in Portugal. J. Clin. Microbiol. 41:2744-2747.

202. Feltus D, Giddings CW, Schneck BL, Monson T, Warshauer D, McEvoy JM. 2006. Evidence supporting zoonotic transmission of Cryptosporidium spp. in Wisconsin. J. Clin. Microbiol. 44:4303-4308.

203. Mallon M, MacLeod A, Wastling JM, Smith H, Tait A. 2003. Multilocus genotyping of Cryptosporidium parvum type 2: population genetics and sub-structuring. Infect. Genet. Evol. 3:207-218.

204. Peng MM, Matos O, Gatei W, Das P, Stantic-Pavlinic M, Bern C, Sulaiman IM, Glaberman S, Lal AA, Xiao L. 2001. A comparison of Cryptosporidium subgenotypes from several geographic regions. J. Eukaryot. Microbiol. 2001(Suppl):28S-31S. doi:10.1111/j.1550-7408.2001 .tb00442.x.

205. Peng MM, Wilson ML, Holland RE, Meshnick SR, Lal AA, Xiao L. 2003. Genetic diversity of Cryptosporidium spp. in cattle in Michigan: implications for understanding the transmission dynamics. Parasitol. Res. 90:175-180.

206. Sulaiman I, Hira PR, Zhou L, Al-Ali FM, Al-Shelahi FA, Shweiki HM, Iqbal J, Khalid N, Xiao L. 2005. Unique endemicity of cryptosporidiosis in children in Kuwait. J. Clin. Microbiol. 43:2805-2809.

207. Thompson H, Dooley JS, Kenny J, McCoy M, Lowery CJ, Moore JE, Xiao L. 2007. Genotypes and subtypes of Cryptosporidium spp. in neonatal calves in Northern Ireland. Parasitol. Res. 100:619-624.

208. Trotz-Williams L, Martin DS, Gatei W, Cama V, Peregrine AS, Martin SW, Nydam DV, Jamieson F, Xiao L. 2006. Genotype and subtype analyses of Cryptosporidium isolates from dairy calves and humans in Ontario. Parasitol. Res. 99:346-352.

209. Widmer G. 2009. Meta-analysis of a polymorphic surface glycoprotein of the parasitic protozoa Cryptosporidium parvum and Cryptosporidium hominis. Epidemiol. Infect. 137:1800-1808.

210. Xiao L, Ryan UM. 2004. Cryptosporidiosis: an update in molecular epidemiology. Curr. Opin. Infect. Dis. 17:483-490.

211. Feng Y, Wang L, Duan L, Gomez-Puerta LA, Zhang L, Zhao X, Hu J, Zhang N, Xiao L. 2012. Extended outbreak of cryptosporidiosis in a pediatric hospital, China. Emerg. Infect. Dis. 18:312-314.

212. O'Connor R, Wanyiri JW, Wojczyk BS, Kim K, Ward H. 2007. Stable expression of Cryptosporidium parvum glycoprotein gp40/15 in Toxoplasma gondii. Mol. Biochem. Parasitol. 152:149-158.

213. Power ML, Cheung-Kwok-Sang C, Slade M, Williamson S. 2009. Cryptosporidium fayeri: diversity within the GP60 locus of isolates from different marsupial hosts. Exp. Parasitol. 121:219-223.

214. Priest J, Kwon JP, Arrowood MJ, Lammie PJ. 2000. Cloning of the immunodominant $17-\mathrm{kDa}$ antigen from Cryptosporidium parvum. Mol. Biochem. Parasitol. 106:261-271.

215. Sestak K, Ward LA, Sheoran A, Feng X, Akiyoshi DE, Ward HD, Tzipori S. 2002. Variability among Cryptosporidium parvum genotype 1 and 2 immunodominant surface glycoproteins. Parasite Immunol. 24: 213-219.
216. Priest JW, Xie LT, Arrowood MJ, Lammie PJ. 2001. The immunodominant $17-\mathrm{kDa}$ antigen from Cryptosporidium parvum is glycosylphosphatidylinositol-anchored. Mol. Biochem. Parasitol. 113:117-126.

217. Gut J, Nelson RG. 1994. Cryptosporidium parvum sporozoites deposit trails of 11A5 antigen during gliding locomotion and shed 11A5 antigen during invasion of MDCK cells in vitro. J. Eukaryot. Microbiol. 41:42S43S.

218. Winter G, Gooley AA, Williams KL, Slade MB. 2000. Characterization of a major sporozoite surface glycoprotein of Cryptosporidum parvum. Funct. Integr. Genomics 1:207-217.

219. O'Hara SP, Chen XM. 2011. The cell biology of cryptosporidium infection. Microbes Infect. 13:721-730.

220. Mead JR, Arrowood MJ, Sterling CR. 1988. Antigens of Cryptosporidium sporozoites recognized by immune sera of infected animals and humans. J. Parasitol. 74:135-143.

221. Reperant JM, Naciri M, Iochmann S, Tilley M, Bout DT. 1994. Major antigens of Cryptosporidium parvum recognised by serum antibodies from different infected animal species and man. Vet. Parasitol. 55:1-13.

222. Riggs MW, Cama VA, Leary HL, Jr, Sterling CR. 1994. Bovine antibody against Cryptosporidium parvum elicits a circumsporozoite precipitatelike reaction and has immunotherapeutic effect against persistent cryptosporidiosis in SCID mice. Infect. Immun. 62:1927-1939.

223. Tilley M, Eggleston MT, Upton SJ. 1993. Multiple oral inoculations with Cryptosporidium parvum as a means of immunization for production of monoclonal antibodies. FEMS Microbiol. Lett. 113:235-240.

224. Soldati D, Dubremetz JF, Lebrun M. 2001. Microneme proteins: structural and functional requirements to promote adhesion and invasion by the apicomplexan parasite Toxoplasma gondii. Int. J. Parasitol. 31:12931302.

225. Adams RB, Guerrant RL, Zu S, Fang G, Roche JK. 1994. Cryptosporidium parvum infection of intestinal epithelium: morphologic and functional studies in an in vitro model. J. Infect. Dis. 169:170-177.

226. Que X, Reed SL. 2000. Cysteine proteinases and the pathogenesis of amebiasis. Clin. Microbiol. Rev. 13:196-206.

227. Shenai BR, Sijwali PS, Singh A, Rosenthal PJ. 2000. Characterization of native and recombinant falcipain-2, a principal trophozoite cysteine protease and essential hemoglobinase of Plasmodium falciparum. J. Biol. Chem. 275:29000-29010.

228. Shin MH, Kita H, Park HY, Seoh JY. 2001. Cysteine protease secreted by Paragonimus westermani attenuates effector functions of human eosinophils stimulated with immunoglobulin G. Infect. Immun. 69:15991604.

229. Forney JR, Yang S, Du C, Healey MC. 1996. Efficacy of serine protease inhibitors against Cryptosporidium parvum infection in a bovine fallopian tube epithelial cell culture system. J. Parasitol. 82:638-640.

230. Miller CM, Akratos C, Johnson AM, Smith NC. 2000. The production of a $70 \mathrm{kDa}$ heat shock protein by Toxoplasma gondii RH strain in immunocompromised mice. Int. J. Parasitol. 30:1467-1473.

231. Woods KM, Tilley M, Iseli A, Upton SJ, Montelone BA, Khramtsoy NV. 1999. Sequence of the gene encoding hsp90e from Cryptosporidium parvum. DNA Seq. 10:339-342.

232. Morgan U, Weber R, Xiao L, Sulaiman I, Thompson RC, Ndiritu W, Lal A, Moore A, Deplazes P. 2000. Molecular characterization of Cryptosporidium isolates obtained from human immunodeficiency virusinfected individuals living in Switzerland, Kenya, and the United States. J. Clin. Microbiol. 38:1180-1183.

233. Sulaiman I, Morgan UM, Thompson RC, Lal AA, Xiao L. 2000. Phylogenetic relationships of Cryptosporidium parasites based on the 70-kilodalton heat shock protein (HSP70) gene. Appl. Environ. Microbiol. 66:2385-2391.

234. Lyons RE, Johnson AM. 1998. Gene sequence and transcription differences in $70 \mathrm{kDa}$ heat shock protein correlate with murine virulence of Toxoplasma gondii. Int. J. Parasitol. 28:1041-1051.

235. Lyons RE, Johnson AM. 1995. Heat shock proteins of Toxoplasma gondii. Parasite Immunol. 17:353-359.

236. Moxon ER, Rainey PB, Nowak MA, Lenski RE. 1994. Adaptive evolution of highly mutable loci in pathogenic bacteria. Curr. Biol. 4:24-33.

237. Deitsch KW, Moxon ER, Wellems TE. 1997. Shared themes of antigenic variation and virulence in bacterial, protozoal, and fungal infections. Microbiol. Mol. Biol. Rev. 61:281-293.

238. Henderson IR, Owen P, Nataro JP. 1999. Molecular switches-the ON and OFF of bacterial phase variation. Mol. Microbiol. 33:919-932.

239. Barry JD, Ginger ML, Burton P, McCulloch R. 2003. Why are parasite 
contingency genes often associated with telomeres? Int. J. Parasitol. 33: $29-45$.

240. Yang X, Figueiredo LM, Espinal A, Okubo E, Li B. 2009. RAP1 is essential for silencing telomeric variant surface glycoprotein genes in Trypanosoma brucei. Cell 137:99-109.

241. Kyes S, Horrocks P, Newbold C. 2001. Antigenic variation at the infected red cell surface in malaria. Annu. Rev. Microbiol. 55:673-707.

242. Kim D, Chiurillo MA, El-Sayed N, Jones K, Santos MR, Porcile PE, Andersson B, Myler P, da Silveira JF, Ramirez JL. 2005. Telomere and subtelomere of Trypanosoma cruzi chromosomes are enriched in (pseudo)genes of retrotransposon hot spot and trans-sialidase-like gene families: the origins of T. cruzi telomeres. Gene 346:153-161.

243. Benfield TL, Lundgren JD. 1998. The Pneumocystis carinii major surface glycoprotein (MSG): its potential involvement in the pathophysiology of pneumocystosis. FEMS Immunol. Med. Microbiol. 22:129-134.

244. Schmuckli-Maurer J, Casanova C, Schmied S, Affentranger S, Parvanova I, Kang'A S, Nene V, Katzer F, McKeever D, Muller J, Bishop R, Pain A, Dobbelaere DA. 2009. Expression analysis of the Theileria parva subtelomere-encoded variable secreted protein gene family. PLoS One 4:e4839. doi:10.1371/journal.pone.0004839.

245. Widmer G, Tzipori S, Fichtenbaum CJ, Griffiths JK. 1998. Genotypic and phenotypic characterization of Cryptosporidium parvum isolates from people with AIDS. J. Infect. Dis. 178:834-840.

246. Petry F, Jakobi V, Tessema TS. 2010. Host immune response to Cryptosporidium parvum infection. Exp. Parasitol. 126:304-309.

247. Flanigan T, Whalen C, Turner J, Soave R, Toerner J, Havlir D, Kotler D. 1992. Cryptosporidium infection and CD4 counts. Ann. Intern. Med. 116:840-842.

248. Schmidt W, Wahnschaffe U, Schäfer M, Zippel T, Arvand M, Meyerhans A, Riecken EO, Ullrich R. 2001. Rapid increase of mucosal CD4 T cells followed by clearance of intestinal cryptosporidiosis in an AIDS patient receiving highly active antiretroviral therapy. Gastroenterology 120:984-987.

249. Kocoshis SA, Cibull ML, Davis TE, Hinton JT, Seip M, Banwell JG. 1984. Intestinal and pulmonary cryptosporidiosis in an infant with severe combined immune deficiency. J. Pediatr. Gastroenterol. Nutr. 3:149-157.

250. Hayward AR, Levy J, Facchetti F, Notarangelo L, Ochs HD, Etzioni A, Bonnefoy JY, Cosyns M, Weinberg A. 1997. Cholangiopathy and tumors of the pancreas, liver, and biliary tree in boys with X-linked immunodeficiency with hyper-IgM. J. Immunol. 158:977-983.

251. Levy J, Espanol-Boren T, Thomas C, Fischer A, Tovo P, Bordigoni P, Resnick I, Fasth A, Baer M, Gomez L, Sanders EA, Tabone MD, Plantaz D, Etzioni A, Monafo V, Abinun M, Hammarstrom L, Abrahamsen T, Jones A, Finn A, Klemola T, DeVries E, Sanal O, Peitsch MC, Notarangelo LD. 1997. Clinical spectrum of X-linked hyper-IgM syndrome. J. Pediatr. 131:47-54.

252. Wolska-Kusnierz B, Bajer A, Caccio S, Heropolitanska-Pliszka E, Bernatowska E, Socha P, van Dongen J, Bednarska M, Paziewska A, Sinski E. 2007. Cryptosporidium infection in patients with primary immunodeficiencies. J. Pediatr. Gastroenterol. Nutr. 45:458-464.

253. Anonymous. 1997. Primary immunodeficiency diseases. Report of a WHO scientific group. Clin. Exp. Immunol. 109(Suppl 1):1-28.

254. Gomez Morales MA, Ausiello CM, Guarino A, Urbani F, Spagnuolo MI, Pignata C, Pozio E. 1996. Severe, protracted intestinal cryptosporidiosis associated with interferon gamma deficiency: pediatric case report. Clin. Infect. Dis. 22:848-850.

255. Clifford CP, Crook DW, Conlon CP, Fraise AP, Day DG, Peto TE. 1990. Impact of waterborne outbreak of cryptosporidiosis on AIDS and renal transplant patients. Lancet 335:1455-1456.

256. Collier AC, Miller RA, Meyers JD. 1984. Cryptosporidiosis after mar- row transplantation: person-to-person transmission and treatment with spiramycin. Ann. Intern. Med. 101:205-206.

257. Gentile G, Venditti M, Micozzi A, Caprioli A, Donelli G, Tirindelli C, Meloni G, Arcese W, Martino P. 1991. Cryptosporidiosis in patients with hematologic malignancies. Rev. Infect. Dis. 13:842-846.

258. McAnulty JM, Keene WE, Leland D, Hoesly F, Hinds B, Stevens G, Fleming DW. 2000. Contaminated drinking water in one town manifesting as an outbreak of cryptosporidiosis in another. Epidemiol. Infect. 125:79-86.

259. Hunter PR, Quigley C. 1998. Investigation of an outbreak of cryptosporidiosis associated with treated surface water finds limits to the value of case control studies. Commun. Dis. Public Health 1:234-238.

260. Chappell CL, Okhuysen PC, Sterling CR, Wang C, Jakubowski W, Dupont HL. 1999. Infectivity of Cryptosporidium parvum in healthy adults with pre-existing anti-C. parvum serum immunoglobulin G. Am. J. Trop. Med. Hyg. 60:157-164.

261. Okhuysen PC, Chappell CL, Sterling CR, Jakubowski W, DuPont HL. 1998. Susceptibility and serologic response of healthy adults to reinfection with Cryptosporidium parvum. Infect. Immun. 66:441-443.

262. Craun GF, Hubbs SA, Frost F, Calderon RL, Via SH. 1998. Waterborne outbreaks of cryptosporidiosis. J. Am. Water Works Assoc. 90:81-91.

263. Swift L, Hunter PR. 2004. What do negative associations between potential risk factors and illness in analytical epidemiological studies of infectious disease really mean? Eur. J. Epidemiol. 19:219-223.

264. Hunter PR, de Sylor MA, Risebro HL, Nichols GL, Kay D, Hartemann P. 2011. Quantitative microbial risk assessment of cryptosporidiosis and giardiasis from very small private water supplies. Risk Anal. 31:228-236.

265. Hunter PR, Zmirou-Navier D, Hartemann P. 2009. Estimating the impact on health of poor reliability of drinking water interventions in developing countries. Sci. Total Environ. 407:2621-2624.

266. Coutinho BP, Oria RB, Vieira CM, Sevilleja JE, Warren CA, Maciel JG, Thompson MR, Pinkerton RC, Lima AA, Guerrant RL. 2008. Cryptosporidium infection causes undernutrition and, conversely, weanling undernutrition intensifies infection. J. Parasitol. 94:1225-1232.

267. Mor SM, Tzipori S. 2008. Cryptosporidiosis in children in sub-Saharan Africa: a lingering challenge. Clin. Infect. Dis. 47:915-921.

268. Hunter P, Hughes S, Woodhouse S, Syed Q, Verlander NQ, Chalmers RM, Morgan K, Nichols G, Beeching N, Osborn K. 2004. Sporadic cryptosporidiosis case-control study with genotyping. Emerg. Infect. Dis. 10:1241-1249.

269. Elwin K, Hadfield SJ, Robinson G, Chalmers RM. 2012. The epidemiology of sporadic human infections with unusual cryptosporidia detected during routine typing in England and Wales, 2000-2008. Epidemiol. Infect. 140:673-683.

270. Van Valen L. 1973. A new evolutionary law. Evol. Theory 1:1-30.

271. Venditti C, Meade A, Pagel M. 2010. Phylogenies reveal new interpretation of speciation and the Red Queen. Nature 463:349-352.

272. Lively CM, Dybdahl MF. 2000. Parasite adaptation to locally common host genotypes. Nature 405:679-681.

273. Engelstadter J, Bonhoeffer S. 2009. Red Queen dynamics with nonstandard fitness interactions. PLoS Comput. Biol. 5:e1000469. doi:10 .1371/journal.pcbi.1000469.

274. Ebert D. 1994. Virulence and local adaptation of a horizontally transmitted parasite. Science 265:1084-1086.

275. Anderson RM, May RM. 1982. Coevolution of hosts and parasites. Parasitology 85(Part 2):411-426.

276. Brubaker RR. 1985. Mechanisms of bacterial virulence. Annu. Rev. Microbiol. 39:21-50.

277. O'Hara SP, Yu JR, Lin JJ. 2004. A novel Cryptosporidium parvum antigen, CP2, preferentially associates with membranous structures. Parasitol. Res. 92:317-327. 
Maha Bouzid is currently a Research Associate at Norwich Medical School, University of East Anglia. Her broad research interests are bacterial and parasitic zoonotic diseases. Her primary interests are the molecular biology, epidemiology, and pathogenesis of waterborne parasites, namely, Cryptosporidium and Giardia. She has a master's in microbiology and a Ph.D. awarded from the University of East Anglia, investigating mechanisms of virulence in Cryptosporidium species using the parasite's

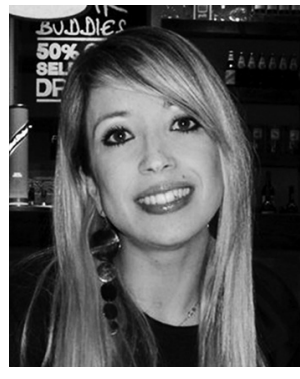
genomics. Her research interest has recently expanded to account for the effect of climate change, mainly on vector-borne and waterborne diseases and other noninfectious climate-sensitive diseases.

Paul R. Hunter is currently Professor of Health Protection at Norwich Medical School, University of East Anglia, where he teaches medical and graduate students. He is also an honorary consultant medical microbiologist in the Norfolk and Norwich University Hospital. He obtained his medical degree and subsequent diploma in Bacteriology and doctor of medicine from the University of Manchester and a master's in Business Administration from the Open University. He specialized in Medical Microbi-

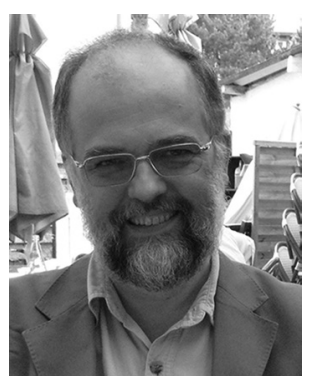
ology and in Communicable Disease Control and is a Fellow of both the Royal College of Pathologists and the Faculty of Public Health of the Royal College of Physicians. The broad focus of his research is on food and waterborne disease, although his primary interests are in the epidemiology of cryptosporidiosis and in disease attributable to very small drinking water supplies. He has undertaken research work in Europe, Africa, Southeast Asia, and the Caribbean.
Rachel M. Chalmers is a Consultant Clinical Scientist and is Head of the national Cryptosporidium Reference Unit for England and Wales, based at the Public Health Wales Microbiology laboratory in Swansea. She has a B.Sc. in Life Sciences from Napier University, Edinburgh, and a Ph.D. in Parasitology from Coventry University. Before undertaking her Ph.D., she worked in veterinary microbiology at the Moredun Research Institute, Edinburgh, where she first became interested in Cryptosporidium. Af ter her Ph.D., she worked on the human epidemiology of zoonoses and waterborne diseases at the Communicable Disease Surveillance Centre in Cardiff, before taking up her present post in 2000.

Kevin M. Tyler is a primary investigator in Eukaryotic Microbiology at Norwich Medical School, University of East Anglia. Research from his laboratory focuses on the pathogenicity of single-celled eukaryotic microbes. In particular, his work to date has focused on the mechanisms of virulence of kinetoplastids and amitochondrial parasites. Programs in his laboratory include cryptosporidiosis, giardiasis, Chagas disease, leishmaniasis, and sleeping sickness. He is broadly interested in the cell and

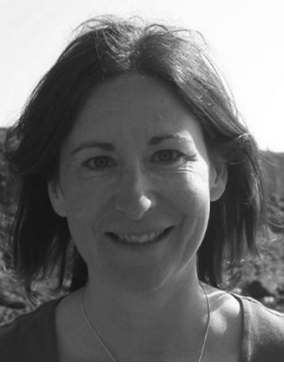
molecular biology of the microbes themselves and of the host responses which they elicit. His studies are unified by an approach which is biology driven but technology led and which exploits parasite genomics toward the identification and exploitation of virulence factors in novel interventions and as epidemiological and taxonomic markers as tools to inform public health policy. 